\title{
Whole-genome sequencing targets drug-resistant bacterial infections
}

\author{
N. V. Punina ${ }^{1 *}$ D, N. M. Makridakis ${ }^{2}$, M. A. Remnev ${ }^{3}$ and A. F. Topunov ${ }^{1}$
}

\begin{abstract}
During the past two decades, the technological progress of whole-genome sequencing (WGS) had changed the fields of Environmental Microbiology and Biotechnology, and, currently, is changing the underlying principles, approaches, and fundamentals of Public Health, Epidemiology, Health Economics, and national productivity. Today's WGS technologies are able to compete with conventional techniques in cost, speed, accuracy, and resolution for day-to-day control of infectious diseases and outbreaks in clinical laboratories and in long-term epidemiological investigations. WGS gives rise to an exciting future direction for personalized Genomic Epidemiology. One of the most vital and growing public health problems is the emerging and re-emerging of multidrug-resistant (MDR) bacterial infections in the communities and healthcare settings, reinforced by a decline in antimicrobial drug discovery. In recent years, retrospective analysis provided by WGS has had a great impact on the identification and tracking of MDR microorganisms in hospitals and communities. The obtained genomic data are also important for developing novel easy-to-use diagnostic assays for clinics, as well as for antibiotic and therapeutic development at both the personal and population levels. At present, this technology has been successfully applied as an addendum to the real-time diagnostic methods currently used in clinical laboratories. However, the significance of WGS for public health may increase if: (a) unified and user-friendly bioinformatics toolsets for easy data interpretation and management are established, and (b) standards for data validation and verification are developed. Herein, we review the current and future impact of this technology on diagnosis, prevention, treatment, and control of MDR infectious bacteria in clinics and on the global scale.
\end{abstract}

\section{Introduction}

Human genomics is inseparably linked to the genomics of bacteria. Bacteria share a long history with humans and play a major role in our life [152, 200]. Beneficial utilization of bacterial products can provide key solutions to many pressing problems on the planet, from environmental pollution to human diseases. Investigation of bacterial pathogens remains agenda priority mainly due to two additional reasons: (i) over $13 \%$ of the world's deaths are related to bacterial infectious disease (including respiratory diseases and tuberculosis (TB)) every year [79, 250], and (ii) the growth of ancient pathogen re-emergence is driven by steadily increasing resistance to multiple widely used antimicrobial agents [59, 60, 249]. Despite the importance and utility of bacteria, until quite recently, little was known about their genomic structure.

\footnotetext{
* Correspondence: hin-enkelte@yandex.ru

'Bach Institute of Biochemistry, Russian Academy of Science, Moscow 119071, Russia

Full list of author information is available at the end of the article
}

During the last two decades, bacteria genomics is rapidly changing, mostly through the evolution of wholegenome sequencing (WGS) technologies. Recent technical advantages significantly reduced the cost of WGS and improved its power and resolution. Since WGS tools (both chemistry and bioinformatics-wise) are changing rapidly, we will not dwell in the details of individual technologies and equipment. The variety and applicability of the major high-throughput sequencing platforms are well presented in several reviews (e.g., $[149,199,263])$.

The advent and ever-growing use of the novel WGS technologies resulted in a rapid intensification in the scope and speed of the completion of bacterial genome sequencing projects. This explosion in bacterial genomics has greatly expanded our view of the genetic and physiological diversity of bacteria. To date, over 39,000 genome projects have been started, approximately 3,000 microbes' whole-genome sequences were completed and published [134, 181, 229], and more than 500 new species are being described every year $[68,112]$. However, 
most of these projects were driven by the potential practical applications of the investigated microorganisms and thus missed most of the microbial diversity on the planet $[133,134,180]$.

Although researchers have only scratched the surface of microbial biodiversity, the information gained has already resulted in the discovery of large numbers of pathogenic bacteria in humans. WGS technologies granted access to potential virulence determinants, disruptive targets, candidate drug compounds [85], mechanisms of pathogenicity, drug resistance and spread [62], and their evolution in pathogens. In addition, WGS analysis provided information about uncultured or difficult-to-grow bacterial strains isolated from clinical specimens [15]. Knowledge of the enormous range of microbial capacities and functional activity can address many epidemiological questions and will have broad and far-reaching implications for personalized and public healthcare in the future. In this field, potential applications of WGS can be essential for:

i. Detection, identification, and characterization of infectious microorganisms

ii. Design of novel diagnostic assays for laboratory use

iii. Assessment of multidrug resistance (MDR) or virulence repertoires in pathogens, as well candidate antimicrobial compounds in beneficial microorganisms

iv. Monitoring the emergence and spread of bacterial infectious agents in different healthcare settings $[46,69,126]$

The WGS technology is very likely to become an alternative to the traditional methods of fighting DR bacteria. Even today, this technology is already used globally as an addendum to complement conventional laboratory approaches (microscopy, pathogenic tests, mass spectrometry, conventional molecular diagnostics, techniques for vaccine and antibiotic design) in routine clinical workflow and scientific investigations $[93,96,149]$. In the future, WGS may simplify the diagnostic laboratory workflow and sample trace, as well as reduce the number and type of collected biological specimens [11, 46, $126,138,201]$. Deploying WGS into individual genome sequencing (IGS) technology has great potential to become a part of routine personalized clinical practice (e.g., TruGenome Clinical Sequencing tests ${ }^{\text {Tu }}$ by Illumina Clinical Services Laboratory; Complete Genomics Platform $^{\text {Ta }}$ by Complete Genomics BGI, Helicos Helicope ${ }^{\mathrm{Tm}}$ by SeqLL; Personal Genome Project) [92]. It is further expected that WGS will permit a deep understanding of infection mechanisms, allow for more rational preventive measures [24], and reduce the risk of unnecessary infection-control interventions [228].
The growing incidence of bacterial resistance to a broad range of antibacterial drugs in hospitals and communities is a major public health threat today and a compelling reason for WGS application. MDR pathogens complicate efforts of infection control and result in considerable morbidity and mortality around the world [111, 131, 217]. Today, MDR infections are recognized as multidimensional global challenge by many health organizations $[26,232,251]$. This complex problem requires comprehensive measures to be solved [42]. It was postulated that effective problem-solving strategies should include: (i) revealing and monitoring infectious agents, (ii) tracking antibiotic resistance, (iii) developing new antimicrobial drugs, (iv) providing rational antimicrobial stewardship program in healthcare institutions in order to avoid inappropriate or excessive antibiotic use, and (v) developing unified toolsets and standards for effective worldwide data management [42, 221, 224].

Taking into account the growing concern about emerging infections, in this review, we detail the main uses and hurdles of WGS technologies in clinical practice and public health with regard to MDR bacterial infections.

\section{Main directions of WGS applications in MDR bacterial infections (review scope)}

There are numerous possible applications of WGS in dealing with infectious disease of MDR bacteria. WGS can be used as a primary tool for:

i. Detection of multidrug susceptibility

ii. Monitoring MDR evolution and transmission dynamics of MDR pathogen

iii. Diagnosis and control of MDR infections locally and regionally

iv. Development of new tests and assays for accurate and rapid MDR bacterial diagnostics in clinics and points-of-care

v. Discovery of novel antibacterial drugs and therapeutics and assessment of their preventability

Each of these tasks is important for clinical and public health and requires methods with different levels of typing resolution. Theoretically, this problem can be addressed by reliable, quick, and low-cost WGS technology in the near future.

\section{Detection of MD susceptibility}

Recently introduced into routine clinical microbiological analysis, WGS has had a great impact on the study of the spectrum of genetic factors involved in MDR to microorganisms and, consequently, on the cost-effectiveness of subsequent disease treatment [214]. Rapid and accurate identification and characterization of known and new 
antibiotic resistance determinants and their arrangements play a key role in preventing the emergence and spread of MDR pathogenic microorganisms in any healthcare setting [214]. Current knowledge of the type of pathogen and its antibiotic resistance profile is essential for selection of therapy and development of new antibacterial drugs $[106,123,214]$ and for reducing the high mortality rate in infected patients. This knowledge also has particular significance for the pathogens causing most frequent and severe types of healthcare-associated and communityacquired infections such as bloodstream (BSI), urinary tract (UTI), and wound stream infections (WSI) [170]. The MDR bacterial pathogens of international concern $[36,161,252]$ are presented in Table 1.

Many chromosome- and plasmid-mediated resistance determinants were successfully identified for most severe pathogenic bacteria using WGS technologies (Table 1). Together with data obtained by classic antimicrobial susceptibility tests [118] and genotyping methods [66], these determinants were deposited into the Antibiotic Resistance Genes Database (ARDB) [146]. Currently, there is an open catalog of more 13,000 antibiotic resistance genes, composing the resistome [253], with rich information, including resistance profile, mechanisms, requirements, epidemiology, coding sequences, and their mutations for more than 250 bacterial genera.

Revelation of the links between genetic and phenotypic traits of bacteria still remains one of the most critical issues that thwart implementation of WGS in clinical and public health practice. Determination of the genetic components of antibiotic resistance (resistant genotypes) and their correlation to resistant bacterial phenotypes can potentially promote its practical application. The possibility to ascertain the phenotypic antimicrobial resistance on the basis of genomic data has been extensively studied [196, 261]. The resistance phenotypes determined based on WGS data were compared to the results of phenotypic tests for methicillinresistant Staphylococcus aureus (MRSA) [82, 103], Clostridium difficile [53], Escherichia coli, Klebsiella pneumonia [100, 218], and Pseudomonas aeruginosa $[41,124]$. The analyses showed that data obtained for these bacteria through WGS can reliably predict antibiotic susceptibility phenotype, with overall sensitivity and specificity more than $95 \%[53,82,218]$. Hence, WGS may be applied as first-line antibiotic resistance screening method in clinical practice of these pathogens. However, it is important to remember that in some cases, bacterial MDR depends on the mode and level of the resistance gene expression [118]. Thus, presence of the genetic resistance determinants does not solely determine MDR phenotype and success/failure of the antibiotic therapy.
Owing to this and other facts (discussed herein), current WGS technology can be clinically applicable only as an integral part of a comprehensive state/government-approved workflow for the clinically relevant cases, e.g., typing of linezolid-resistant Enterococcus faecium or screening of carbapenem-resistant Enterobacteriaceae $[101,194]$. Future investigations of pathogen resistance mechanisms together with establishment of robust links between genetic components and phenotypic traits in MDR bacteria will help the development of successful WGS-based antibiotic resistance tests. Development of standardized procedures for validation and verification of WGS data, as well user-friendly bioinformatics tools for quick handling and analysis of the genomic information will speed up the implementation of WGS technologies into laboratory practice. For example, one of these tools is provided by the Center for Genomic Epidemiology [136].

\section{Investigation of MDR evolution and emergence dynamics}

WGS has been used for the study of the evolution of resistance (or proto-resistance) to multiple drugs and its emergence in different healthcare settings [182]. Largescale worldwide studies showed that this method could be applied to elucidate historical antibiotic resistance patterns in pathogen populations and study infection transmission mechanisms and emergence dynamics. Specifically, WGS technologies allowed uncovering the genetic basis behind the emergence/re-emergence of successful clones in outbreaks and measuring the rates at which resistance emerges. In addition, WGS also elucidated some of the etiologic factors that allow pathogenesis and spreading MDR bacteria [93, 143, 190].

WGS revealed that the speed of bacterial MDR evolution depends on the genome plasticity and epidemiology of the pathogen, as well as type and duration of applied antibacterial treatment in healthcare settings. For example, the number of SNPs and structural variations (SVs) was higher in MRSA clones in under-resourced healthcare settings where barriers to transmission were lower [227]. Furthermore, the number of SNP differences between isolates belonging to the same outbreaks positively correlated to the time of their isolation in case of MRSA and Mycobacterium tuberculosis, pathogens which are transmitted strictly from human to human within a hospital community [52, 95, 127, 227, 258]. In contrast, studies of Salmonella enterica subsp. enterica and subsp. typhimurium, pathogens which can be transmitted from human to human indirectly through various sources, did not show any impact on the accumulated SNP numbers [141, 178]. Genomic analysis also extended our knowledge about the origin of MDR evolution in bacterial populations demonstrating that evolution is acquired through at least three ways: 
Table 1 Common MDR bacterial agents of epidemiological importance causing severe infections in hospitals (H) and communities (C)

\begin{tabular}{|c|c|c|c|}
\hline Bacterial agent & Diseases & Resistance & $\begin{array}{l}\text { Example of main resistance determinants revealed in } \\
\text { whole sequenced genomes }\end{array}$ \\
\hline \multirow[t]{2}{*}{ Escherichia coli $(\mathrm{H}, \mathrm{C})$} & \multirow[t]{2}{*}{ UTI, BSI } & $\beta$-Lactams (cephalosporins) & $a m p C, 2$ copies of bla $[74]$ \\
\hline & & Quinolones (fluoroquinolones) & $\begin{array}{l}\text { gyrA (Ser83Leu,Asp87Asn), parC (Ser80lle,Glu84Gly) } \\
{[74,188]}\end{array}$ \\
\hline \multirow[t]{4}{*}{ Klebsiella pneumonia $(\mathrm{H}, \mathrm{C})$} & \multirow[t]{4}{*}{ UTI, BSI, pneumonia } & $\begin{array}{l}\beta \text {-Lactams (cephalosporins, } \\
\text { carbapenems) }\end{array}$ & $\begin{array}{l}\text { bla } a_{S H V-75}, \text { bla } a_{S H V-60}, b l a_{K P C-2} \text { bla } a_{T E M-1}, \text { bla } a_{T E M-12} \text {, bla } a_{P 1} \text {, } \\
\text { bla } a_{C T X-M} \\
{[132,145]}\end{array}$ \\
\hline & & Quinolones (fluoroquinolones) & $\begin{array}{l}\text { anrA1, qnrB4, oqxAB, gyrA (Ser 83Phe), parC (Ala339Gly, } \\
\text { Asp641Tyr) [209] }\end{array}$ \\
\hline & & Amynoglycosides & $\operatorname{armA}$, aph [209] \\
\hline & & Colistin & IS1 insertion in the $\operatorname{mgrB}[95,209]$ \\
\hline \multirow[t]{5}{*}{ Staphylococcus aureus $(\mathrm{H}, \mathrm{C})$} & \multirow[t]{5}{*}{ WSI, BSI } & $\beta$-Lactams (methicillin) & $\operatorname{mec} C[157]$ \\
\hline & & Aminoglycosides & $\operatorname{aadD}[258]$ \\
\hline & & Mupirocines & iles-2 [258] \\
\hline & & Mercury resistance & mer operon [258] \\
\hline & & Antiseptic resistance & qacA [258] \\
\hline \multirow[t]{2}{*}{ Streptococcus pneumonia (C) } & \multirow{2}{*}{$\begin{array}{l}\text { Pneumonia, meningitis, } \\
\text { otitis }\end{array}$} & $\beta$-Lactams & pbp2a, pbp2b, pbp2x, spr1238 [56] \\
\hline & & Tetracycline & rpsJ, patA, patB [153] \\
\hline \multirow{3}{*}{$\begin{array}{l}\text { Salmonella enterica subsp. } \\
\text { enterica, Typhimurium, } \\
\text { Choleraesuis (C) }\end{array}$} & \multirow{3}{*}{$\begin{array}{l}\text { Salmonellosis, foodborne } \\
\text { diarrhea, BS }\end{array}$} & $\beta$-Lactams & bla ${ }_{O X A-30}, a m p C, b l a_{T E M-1}, b l a_{T E M-67}[31,91]$ \\
\hline & & Quinolones (fluoroquinolones) & gyrA (Ser83Leu), parC (Ser80Leu), acrAB-tolC [31] \\
\hline & & Aminoglycosides & $\begin{array}{l}2 \text { copies aadA1, } 3 \text { copies aadA3, aac } 3 \text {, aph, strA, strB, sat- } 1 \\
{[91,109]}\end{array}$ \\
\hline \multirow[t]{3}{*}{ Shigella spp. (C) } & \multirow[t]{3}{*}{ "Bacillary dysenteria" } & $\beta$-Lactams & bla $a_{T E M-1}, b l a_{O X A-1}[257]$ \\
\hline & & Fluoroquinolones & mutated parC and gyrA [257] \\
\hline & & Aminoglycosides & $\operatorname{aadA1}$, aadA2, sat-1 [257] \\
\hline \multirow[t]{2}{*}{ Neisseria gonorrhoeae (C) } & \multirow[t]{2}{*}{ Gonorrhea } & $\begin{array}{l}\beta \text {-Lactams (3rd gen. } \\
\text { cephalosporins) }\end{array}$ & $\begin{array}{l}\text { mtrR (G45D, A39T), mtrCDE (del1327932), penB (G101K, } \\
\text { A102D), penA (mosaic) }[54,83,240]\end{array}$ \\
\hline & & Tetracycline & rpsJ (V57M), tetM including its promoter, penB [54] \\
\hline $\begin{array}{l}\text { Coagulase-negative } \\
\text { Staphylococci spp. } \\
\text { (CoNS) }(\mathrm{H}, \mathrm{C})\end{array}$ & SSI, endocarditis, and BSI & $\beta$-Lactams & blaZ, mecC $[25,173,184]$ \\
\hline \multirow[t]{4}{*}{ Enterobacter aerogenes $(\mathrm{H})$} & \multirow[t]{4}{*}{ SSI and BSI } & $\beta$-Lactams & bla $a_{T E M-24,} 2$ copies ampC, 3 copies $M$-bla, 4 copies bla [48] \\
\hline & & Quinolones & gyrA (Thr83lle), parC (Ser80lle) [47, 48] \\
\hline & & Aminoglycosides & $\operatorname{aadA1}, \operatorname{aac}\left(6^{\prime}\right)[47,48]$ \\
\hline & & Rifampicin & rpoB (Asp252Tyr) $[47,48]$ \\
\hline \multirow[t]{6}{*}{$\begin{array}{l}\text { Acinetobacter baumannii } \\
(\mathrm{H}, \mathrm{C})\end{array}$} & \multirow[t]{3}{*}{$\begin{array}{l}\text { BSIs, VAP, HAP, SSI, } \\
\text { CA-UTI, ventilator- } \\
\text { associated pneumonia }\end{array}$} & $\begin{array}{l}\beta \text {-Lactams (3rd gen. } \\
\text { cephalosporins) }\end{array}$ & 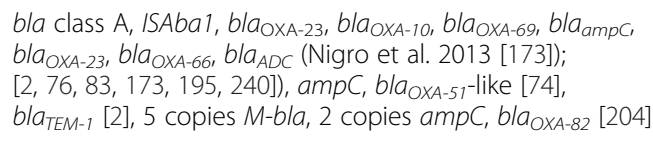 \\
\hline & & Amynoglycosides & $\begin{array}{l}\text { Modified } \operatorname{arm} A, \operatorname{aac}\left(3^{\prime}\right), \operatorname{aac}(3)-1 a, \operatorname{aac}(6) \text {, aac(2)-1b, } \\
\operatorname{aadA1}, \operatorname{aad} A B, \operatorname{aphA1}, \operatorname{aph}\left(3^{\prime}\right), \operatorname{aph} 6, \operatorname{str} A B[2,71,204, \\
\text { 254, 265] adeT, aadA2 [204] }\end{array}$ \\
\hline & & Quinolones & gyrA (Ser83Leu), parC (Ser80Leu) $[2,71,204]$ \\
\hline & \multirow{3}{*}{$\begin{array}{l}\text { BSIS, VAP, HAP, SSI, } \\
\text { CA-UTI, ventilator- } \\
\text { associated pneumonia }\end{array}$} & Colistin & $\operatorname{pmrB}[90]$ \\
\hline & & Tetracyclines & tetAR, adeB $[2,265]$, bcr $[204]$ \\
\hline & & Chloramphenicol & $\mathrm{cm} / \mathrm{A}, \mathrm{cm} / \mathrm{A5}$, cat [71], catB6 [265], catB8 [254], cmr [204] \\
\hline \multirow[t]{2}{*}{$\begin{array}{l}\text { Pseudomonas aeruginosa } \\
(\mathrm{H}, \mathrm{C})\end{array}$} & \multirow[t]{2}{*}{$\begin{array}{l}\text { BSIs, VAP, HAP, SSI, } \\
\text { CA-UTI, cystic fibrosis (CF) }\end{array}$} & $\begin{array}{l}\beta \text {-Lactams (3rd gen. } \\
\text { cephalosporins) }\end{array}$ & blal $_{M P-1}$, oprD [163] ampCDR [124] \\
\hline & & Quinolones & gyrA (Thr83lle), parC (Ser87Leu) [247] \\
\hline
\end{tabular}


Table 1 Common MDR bacterial agents of epidemiological importance causing severe infections in hospitals (H) and communities (C) (Continued)

\begin{tabular}{|c|c|c|c|}
\hline & & Aminoglycosides & $\begin{array}{l}\operatorname{aac}\left(6^{\prime}\right)[163], a p h, a n t\left(4^{\prime}\right)-I l b, \operatorname{str} A B \text { [247], aacA29al } \\
\operatorname{aacA29b}[124]\end{array}$ \\
\hline & & Colistin & pmrAB, phoPQ [247] \\
\hline & & $\begin{array}{l}\text { Wide range of antibacterial } \\
\text { agents }\end{array}$ & 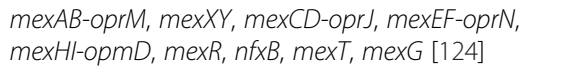 \\
\hline \multirow{3}{*}{$\begin{array}{l}\text { Mycobacterium } \\
\text { tuberculosis }(\mathrm{H}, \mathrm{C})\end{array}$} & \multirow[t]{3}{*}{ Tuberculosis } & Rifampicin & $r p o B(S 450 \mathrm{~L})[52]$ \\
\hline & & Isoniazid & katG (P7 frameshift), ptrBa, fadD15, ppsB, atsH [88] \\
\hline & & $\begin{array}{l}\text { Fluoroquinolone ethambutol } \\
\text { amikacin para-aminosalicylic acid }\end{array}$ & $\begin{array}{l}\text { gyrB (T500N), embB (D1024N), rrs(A514C, A1401G), } \\
\text { thyA (P17L) [52] }\end{array}$ \\
\hline
\end{tabular}

$B S I$ bloodstream infection, SSI surgical-site infection, CA-UTI catheter-associated urinary tract infection, VAP ventilator-associated pneumonia, HAP hospital-acquired pneumonia, WSI wound stream infection, UTI urinary tract infection

i. Transmission of plasmids bearing diverse antimicrobial resistance genes between pathogens/or horizontal gene transfer with the help of mobile genetic elements (MGEs) [12, 37, 179]

ii. Mutations in bacterial drug-related genes and intergenic regions [2, 47, 48, 52, 71, 74, 99, 247]

iii. Differential expression of genes which mediate drug effects [262]

Acquisition of new resistance genes and virulent determinants by horizontal transfer via conjugation, transduction, or transformation usually is associated with pathogen adaptation to new niches or lifestyles and affects the evolution of its genomic content, leading to clinically significant effects. This evolution mostly underlies the success of the MDR emerging strains and may be a major reason of the outbreaks all over the world. Transmissible plasmids and phages frequently bear resistance genes/cassettes conferring bacterial resistance to one or several different antibiotics and facilitate their transfer through different genera. For example, it was revealed that IncA/C plasmids carry extended-spectrum $\beta$ lactamases, AmpC $\beta$-lactamases, and carbapenemases among broad host range pathogenic Enterobacteriaceae $[63,73,100,158,210,212]$. They are considered the most common reason of hospital MDR of these bacteria for many old and new generations of the $\beta$-lactams, including cephalosporins, penicillins, cephamycins, and monobactams $[110,162]$ (Table 1$)$. Other clinically relevant plasmids include pTW20_1, harboring qacA (encoding antiseptic resistance) and mer operon (mercury resistance), and pPR9-like carrying aadD (aminoglycoside resistance) and ileS-2 (resistance to mupirocin) genes, are conjugated between MRSA ST 239 isolates [227] and, possibly, can be transmitted between other staphylococcal strains and species $[9,17]$.

The horizontal gene transfer of chromosomal genes with the help of MGEs is also important in conferring resistance to a wide variety of antibiotics, particularly towards new ones. For instance, recent retrospective studies of $S$. aureus showed that all emergent MRSA populations differed from methicillin-sensitive $S$. aureus (MSSA) not only in plasmid replacement and content but also in such genetic features as small deletion/insertion polymorphisms (DIPs) and presence of MGEs and resistance genes on the chromosome [230, 231, 241]. Further, it was shown that MDR genes are often associated with the MGEs and, with their help, can be transferred to other bacteria between the same or different species [225, 254]. For example, it was shown that the evolution of methicillin resistance in nosocomial and community-acquired MRSA was mostly arisen by acquisition of the staphylococcal cassette chromosome (SCCmec type IV cassette) integrated into the chromosome and carrying the $m e c A$ or $m e c C$ genes encoding penicillin-binding proteins, which reduced affinity for $\beta$ lactam antibiotics [76, 205].

Other recent large-scale studies extended our knowledge about resistance evolution of S. aureus CC398 lineage, the most prevalent emerging pathogen with broad host tropism in many European countries [157, 245]. These works shed light on the nature of MDR in CC398 and questioned its origin and the major reasons of its emergence in clinics. All human-specific MSSA and MRSA isolates carried two unique genetic markers: $\phi 7$ bacteriophage and $\phi 3$ bacteriophage with human-specific immune evasion genes $c h p, s c n$, and sak (only in MRSA) [157]. Based on these studies, it was hypothesized that livestock-associated MRSA has diverged from the humanassociated MSSA and that it acquired tetracycline and methicillin resistance genes and lost phage-carried human virulence genes [157, 192, 213]. However, further discretetrait analyses provided for this lineage did not support the hypothesis about its human origin and left the question about evolutionary routes open [245]. This discrepancy may be explained by the lack of unified and standardized computational methods and interpretative algorithms applied for the WGS data analysis. 
The WGS data, accumulating for various bacterial species, also showed that specific acquired determinants (mostly, virulence-related genes or islands) can also be the key reasons of the emergence of MDR pathogens causing outbreaks. For instance, it was shown that PantonValentine toxin and sas $X$ gene, encoding a surface protein, contributed to the outbreaks caused recently by MRSA in the UK and China, respectively [93, 143]. Further, the $m g r B$ gene, encoding a transmembrane protein produced upon activation of the PhoPQ signaling system, was found to be associated with colistin resistance in re-emergent $K$. pneumonia causing nosocomial outbreaks worldwide [190].

Antibiotic resistance can also be caused by spontaneous and induced missense mutations within the antibiotic targets or their binding sites, e.g., gyrase subunits $\mathrm{A}$ and $\mathrm{B}$, gyrA and $g y r B$ (targets of quinolones), RNA polymerase subunit $\mathrm{B}$, rро $B$ (target of rifampicin), dihydrofolate reductase, alr (rimethoprim), protein biotin ligase, birA (Bio-AMS), or membrane proteins (e.g., multidrug efflux protein norM) (Table 1) [99]. For example, WGS revealed the mutations in blaI, blaR1, as well as in the mecA regulone (mecI-mecR1-mecA) in MRSA [16]. Similarly, it was demonstrated that the major mechanism of MDR in re-emergent $M$. tuberculosis is primarily arisen by point mutations in rрoB (S450L), katG (P7 frameshift), gyrB (T500N), embB (D1024N), rrs (A514C and A1401G), and thyA (P17L) genes [22, 52, 88, 186, 242].

The genomic information together with powerful bioinformatics tools made it possible to distinguish the molecular pathways responsible for MDR-caused diversity. For example, Darch and colleagues have demonstrated that distinct recombination events were the dominant driver of phenotypic diversity in extant population of $P$. aeruginosa obtained from a single cystic fibrosis $(\mathrm{CF})$ patient (with a weight of recombination relative to mutation, $\mathrm{r} / \mathrm{m}$, rate approaching 10) [41]. Other retrospective studies identified the exact unique genetic SNVs in main virulence-related genetic factors of $P$. aeruginosa associated with epidemic CF infection [81]. The increased resistance of emerging MDR $P$. aeruginosa to antibiotics was explained by SNPs enrichment of the efflux pumps which actively transport the toxic compound out of the bacterial cell to avoid contact with the target site $[45,113]$. Similarly, the revealed genome-wide recombination events in chromosomal $\beta$-lactamase genes $b l a_{\mathrm{ADC}}$ and $b l a_{\mathrm{OXA}-51 \text {-like, }}$ plasmid-borne resistance genes, as well transposon- and integron-derived modules were also proposed as major drug resistance diversification drivers for epidemic strains of Acinetobacter baumannii [215, 254].

Revealed SNPs and SNVs can be potentially used as a molecular clock to prognose new or potentially emerging/ re-emerging outbreak strains, precise tracking, early warning, and targeted infection control of pathogenic bacteria. For instance, the time frame for the emergence of a bacterial pathogen clone and its evolution during epidemic spread had been estimated for MRSA [95]. On the basis of the WGS data, the level of nucleotide substitutions was estimated at $1.68 \times 10^{-6}$ substitutions per site per year in the BEAST analysis, or 2.72 mutations per megabase per year in the parsimony [245, 258]. This translates to approximately one mutation per genome every $6-10$ weeks [95]. Taking into account that $1-3$ point mutations or large genetic rearrangements (recombination more than $100 \mathrm{bp}$ ) in targets related with drug resistance are enough to make differences in antibiotic susceptibility, the provisional prediction of an emergence of novel MRSA clones in clinical settings can be afforded [53, 95]. However, another work demonstrated that using a simple threshold of a maximal number of mutations to rule out direct transmission and emergence of MDR M. tuberculosis led to inaccurate interpretation of the data [52]. These authors showed that about $38 \%$ of all individual SNPs were involved in resistance of MDR M. tuberculosis and made an important contribution to evolution and emergence of MDR in the bacteria within a single patient [52].

In summary, together with developed tools for WGS data analysis (e.g., Rainbow [264]) and unifying genomewide database (e.g., M. tuberculosis Variation Database (GMTV) [29], The Bacterial Isolate Genome Sequence Database (BIGSdb) [116]) containing the broad spectrum information about individual mutations of pathogens, WGS can be a powerful tool for the preliminary prediction of drug resistance, geographical origin, as well clinical strategies and outcomes.

\section{Diagnostics and control of MDR bacterial infections}

Successful containment and prevention of MDR infections involves (i) timely identification and characterization of the MDR infectious/outbreak cause, and (ii) discovery of its source and transmission pathways [86, 222, 249]. A significant transformation in MDR infectious disease diagnostics has occurred during the past few decades, including key changes in basic concepts, data analysis approaches, and, especially, methods of exposure measurement and pathogen surveillance [10]. Today, diagnosis of DR pathogenic bacteria are mainly done by means of expensive and time-consuming experimental approaches, including complex phenotypic and genotypic standardized methods [68, 169, 205, 206, 222, 235] (Fig. 1). The techniques applied for this task are mostly based on the detection of phenotypic and genetic traits related to drug resistance, pathogenicity or survival mechanisms of pathogens. Standardized culture-based methods [235], traditional typing (such as biotyping, antibiograms, resistograms), and molecular typing techniques $[68,206,222]$ are widely used 


\section{PHENOTYPIC CHARACTERISTICS}

CHEMOTAXONOMIC
COMPOSITION
e.g.,
Fatty acid profiling
Carbohydrate profiing
Ubiquinone profiling
Polar lipid profiling
Cell wall composition
analysis

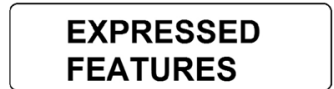

e.g.,

Morphological typing

Physiological typing

Enzymological typing

Serological typing

Phage and bacteriocin

typing

\section{PROTEINS}

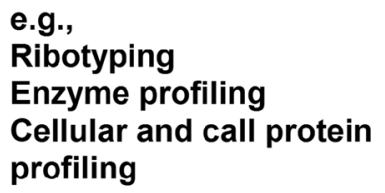

e.g.,

Cellular and call protein

profiling

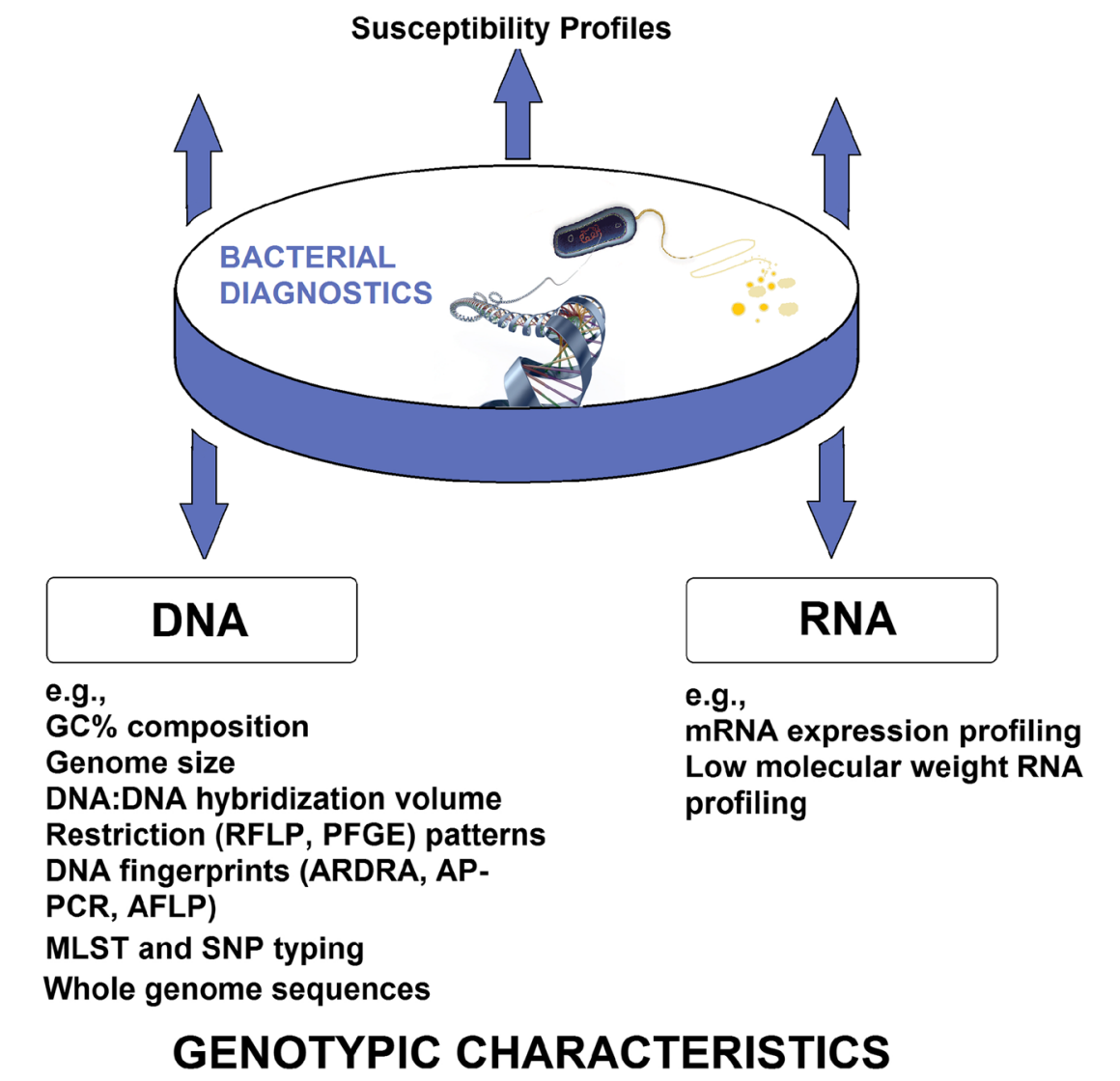

Fig. 1 Main characteristics used for the identification and diagnostics of pathogenic bacteria

to detect and identify the cause and course of the outbreaks in the clinical laboratories. Over the last few years, these methods have improved dramatically: they have incorporated automation to increase speed, discrimination power, and throughput, and reduce cost. However, none of these methods is considered optimal for all forms of research and infections. Choice of the method significantly depends on the epidemiological problem to solve, time constrains, its reliability, accuracy, and geographical scale of its use [206]. Furthermore, almost all available approaches have limitations detecting pathogenic microorganisms with rapid transmission dynamics and mutational rates [169], or mixed MDR infections involving multiple unrelated strains or outbreaks caused by closely related isolates [201]. As a result, existing integrated approaches are laborious, timeconsuming, expensive, and can lead to misdiagnosis.

Although most of the WGS investigations were retrospective, they demonstrated that WGS technology may make real-time genomic diagnostics a reality [117]. In contrast to multifaceted algorithms used in standard testing, genomic data can provide rapid and accurate detection and control of emerging MDR pathogenic strains in a single process, reducing unnecessary infection-control measures [228]. The genomic information affords unprecedented and detailed insight into microevolution of pathogenicity factors, antibiotic resistance, and transmission mechanisms of pathogens, and, thus, allows robust detection and control of the spread of closely related 
pathogenic isolates in the clinics [14, 130, 142, 239], communities [30, 72, 77, 84, 159, 203], and globally [15, 94, 95, 168, 227].

The first application of WGS technology was for MRSA, the leading cause of healthcare-associated infections worldwide $[45,55,171,172,258]$. WGS techniques detected closely related MRSA clones associated with putative outbreaks, which could not be confirmed with conventional methods, and allowed the reconstruction of local and intercontinental spread of MRSA lineages $[53,93,95,127,130,258]$. For instance, Harris and colleagues studied a putative MRSA outbreak on a special care baby unit at a National Health Service Foundation Trust in Cambridge, UK. During these studies, the cause of a persistent outbreak, a new type ST2371 with Panton-Valentine leucocidin encoding gene, was revealed. WGS technique provided the best discrimination between closely related bacterial clones of the same MRSA lineage, compared to multilocus sequencing typing (MLST) analysis [93]. Importantly, this study resulted in a fundamental shift in the understanding of transmission dynamics and sources of successful epidemic MRSA clones between healthcare facilities and communities. WGS provided strong evidence that community-associated MRSA can be carried for a long period by healthy people $[75,93]$ and become the cause of healthcare-acquired MRSA infections replacing dominant healthcare-associated lineages [80]. These data facilitated improved infection-control measures for the infectious sources (e.g., workers, visitors, equipment). Later, this study was complemented with more detailed investigations of cause and sources of hospital- and community-associated MRSA lineages in settings with extensive and poor infection-control practices all over the world [157, 227, 248]. It was shown that low resource countries can be the main source of the global emerging MRSA [227]. Thus, the population of MRSA ST239 lineage, aka the Brazilian clone most prevalent across the globe, was significantly more variable (evolved faster) in countries with low-cost prevention planning and implementation than in those with well-resourced healthcare settings [200, 227]. Another work provided evidence for frequent transfer of most prevalent humanand animal-associated MDR MRSA CC398 lineage and indicated that livestock and animals could be the main source of infection in humans [245]. The fact that $S$. aureus could be transferred between humans, animals, and livestock (probably in all directions) raised the main concern for clinicians. Together with evidence for higher levels of MDR in the livestock-associated clades, this raised the need to change the existing biosecurity control in agricultural settings.

Pallen and colleagues were the first who applied WGS technology to study the prolonged hospital outbreak of
MDR A. baumannii in Birmingham, England, between July 2011 and February 2013. With the help of WGS, a novel isolate, the causative outbreak agent was revealed $[142,177]$. This clone could not be detected by conventional methods. As in the case of MRSA, it was revealed that early transmission events can occur through the ward-based contact and environmental contamination of the hospital environment [177]. This knowledge led to tighter ward decontamination procedures and infectioncontrol interventions with the purpose of reducing the risk of further transmission.

WGS has shown potential for elucidation of the transmission dynamics of the MDR Salmonella species $[6,177]$ and for the detection of various epidemic S. enterica subspecies [141, 174, 175]. MDR and highly clonal lineages of K. pneumonia, an important opportunistic pathogen associated with nosocomial and community-acquired infections [189], can be also successfully detected through WGS [151]. In addition to results for MRSA and A. baumannii which showed strong evidence of transmission via alternative routes (e.g., silent transmission vectors), the retrospective genomic analysis of the nosocomial carbapenemresistant $K$. pneumonia isolates together with epidemiological data revealed unexpected transmission, perhaps through asymptomatic carriers or inanimate objects (ventilators, equipment). In addition, it was concluded that combination of the genomic and patient trace data together with algorithms which accounted for $K$. pneumoniae's capacity for silent colonization can be used for more effective control of the outbreaks and reconstruction of the most likely pathogen transmission routes [216].

WGS analysis allowed identification and tracing of MDR M. tuberculosis more precisely than the currently used conventional typing methods [67, 77, 121, 152, 202, 209, 242]. Using WGS technology, Walker and colleagues first analyzed TB cases of the community outbreaks in the UK Midlands. Only genomic data allowed elucidation of the genetic diversity and detection of closely related mycobacterial genotypes causing these outbreaks [242].

Due to the complexity of antibiotic susceptibility regulation mechanisms in $P$. aeruginosa and the high level of its diversity, the most indisputable WGS implication was usually related to diagnostic and control of CF infections [41, 165]. A number of recent studies of MDR $P$. aeruginosa from a single patient have shown that this technology has a great potential for routine diagnostics and antibiotic susceptibility detection in a clinically relevant time frame [41, 124, 247]. It was proposed that further investigation of the enabling gene pool and resistance mechanisms of MDR $P$. aeruginosa populations could improve clinical outcomes of antibiotic sensitivity and detection testing in the future [41].

Besides the retrospective studies, the real-time WGS analysis was successfully applied for rapid detection of 
infections and outbreaks caused by neonatal MRSA [53, 130], verocytotoxin-producing E. coli (VTEC) [114, 120], Legionella sp. [198], carbapenem-resistant $K$. pneumoniae [216], C. difficile [53], and A. baumannii [204]. For instance, in 2011, real-time WGS clarified the cause of a very mysterious outbreak in a farm in Germany. The outbreak was caused by enteroaggregative E.coli O104:H4 clone, epidemiologically linked to human cases and transmitted via contaminated seeds [84, 195, 203, 233]. Another modification of real-time WGS analysis, direct real-time WGS (sequencing clinical specimens without the need for culture), was successfully applied for identification and characterization of slowly growing and difficult-to-culture pathogens in clinical samples $[7,98,150,211]$. Whereas direct WGS is considered as not cost-effective and less sensitive for some clinical workflows (e.g., in the case of fecal samples or mixed infections) [126], single-colony sequencing is considered a very promising epidemiological tool which can address multiple clinically relevant questions more accurately and faster in the future [129]. A simple WGS protocol has been developed and tested for the detection of a broad range of pathogenic bacteria (17 most clinically important pathogens) from a single bacterial colony $[3,129]$. Once the procedure is validated, this method has a lot of advantages for clinical practice [3]. However, the single-colony WGS method may be difficult to optimize in the case of difficult-to-grow pathogens [41].

Although it is presumed that WGS may become the primary tool to provide pathogen diagnostics and control in clinical and healthcare settings in the nearest future, many obstacles remain [126]. Today, real-time genomic diagnosis is mostly based on the detection of SNP, SNV, and SV of relevant multiple genetic loci selected for typing. The housekeeping, structural, and functional genes and intergenic regions $[11,30,53,77,95,126,136,140,142,156$, $168,195,203,260]$, as well as the virulent and resistance factors are considered as clinically important markers and are applicable for benchtop typing [206]. Growing WGS data and advances in sequencing technologies constantly lead to the discovery of new genetic or genomic variations important for bacterial growth, pathogenesis, antibiotic resistance, and survival. However, before being applied for diagnostics, this plethora of biomarkers requires intensive study of their functions and associations with particular phenotypic changes. Subsequently, the simple and unified analytical tools/platforms to readily extract relevant information from the genome and interpret it without complex and computer-intensive analysis should be developed, and the clinical health personnel should have a quick access to them $[135,136,140,256]$. One example of this strategy is the study of Neisseria meningitidis outbreak [57, 78, 115] which occurred at the University of Southampton, UK, in 1997. Jolley and colleagues developed an integrated analysis platform and applied it for the robust interpretation and analysis of WGS data obtained for $N$. meningitidis. As a result, this analysis took only a few minutes and permitted complete resolution of the meningococcal outbreak. While these tools are being developed for self-contained laboratory workflow, the integration of the WGS technology with phenotypic, molecular typing methods [39, 40], new strategies of sample and culture selection [68], and epidemiologic data analysis is already enhancing our ability to control and prevent nosocomial or healthcare-associated infections.

\section{Development of new diagnostics markers and assays}

While WGS sequencing is highly informative, it is not cheap, fast or readily available for screening DR bacterial isolates in various healthcare settings today. For example, current WGS technologies may be too slow for point-ofcare diagnostics. As a result, target-specific PCR, real-time PCR, and related technologies [160, 223] still remain the most common methods used in clinical practice. However, it still remains critical to select specific sequences (signatures/targets) for designing molecular assays for the pathogen of interest [5]. In this case, WGS can act as a precursor to generate specific diagnostic tests for timely case definition [102, 193, 219]. The genomic data should be analyzed using computational methods (e.g., KPATH, TOFI, Insignia, TOPSI, ssGeneFinder, or alignment-free methods) in order to identify pathogen signatures, estimate their evolutionary rates across the group, and design highly specific diagnostic assays for target groups of pathogens [104, 193]. Due to the obtained WGS data, numerous novel diagnostic genetic targets have been suggested for routine diagnostics of several pathogenic bacteria over the last few years. An extensive list of putative markers is presented in Table 2. WGS technology can also provide robust information about the reliability of the existing and implemented diagnostic markers and thus can help in avoiding false-negative and false-positive results. For example, the obtained WGS data improved the current diagnostic, cultural, and molecular tests for several pathogens: S. aureus [184], TB [125], E. coli [51], and K. pneumoniae [48].

\section{Developing new antibacterial drugs}

Today, a lot of strategies are applied to optimize the identification of new targets and their inhibitors (antibacterial compounds, hits) for the discovery of new antibacterial drugs $[50,214]$ and predict the mechanisms of their action and their effects in patients. However, clinical management of drug-resistant strains still remains cumbersome. At the same time, the number of newly approved drugs per year has been decreasing, and only five new antibiotics were approved since $2003[18,49]$. WGS can assist this effort by accelerating the discovery of novel antibacterial inhibitors and targets overlooked by conventional discovery platforms, e.g., sputum smear, culture, and drug susceptibility 
Table 2 List of the putative genetic markers obtained by WGS for diagnostics of the bacterial agents of epidemiological importance

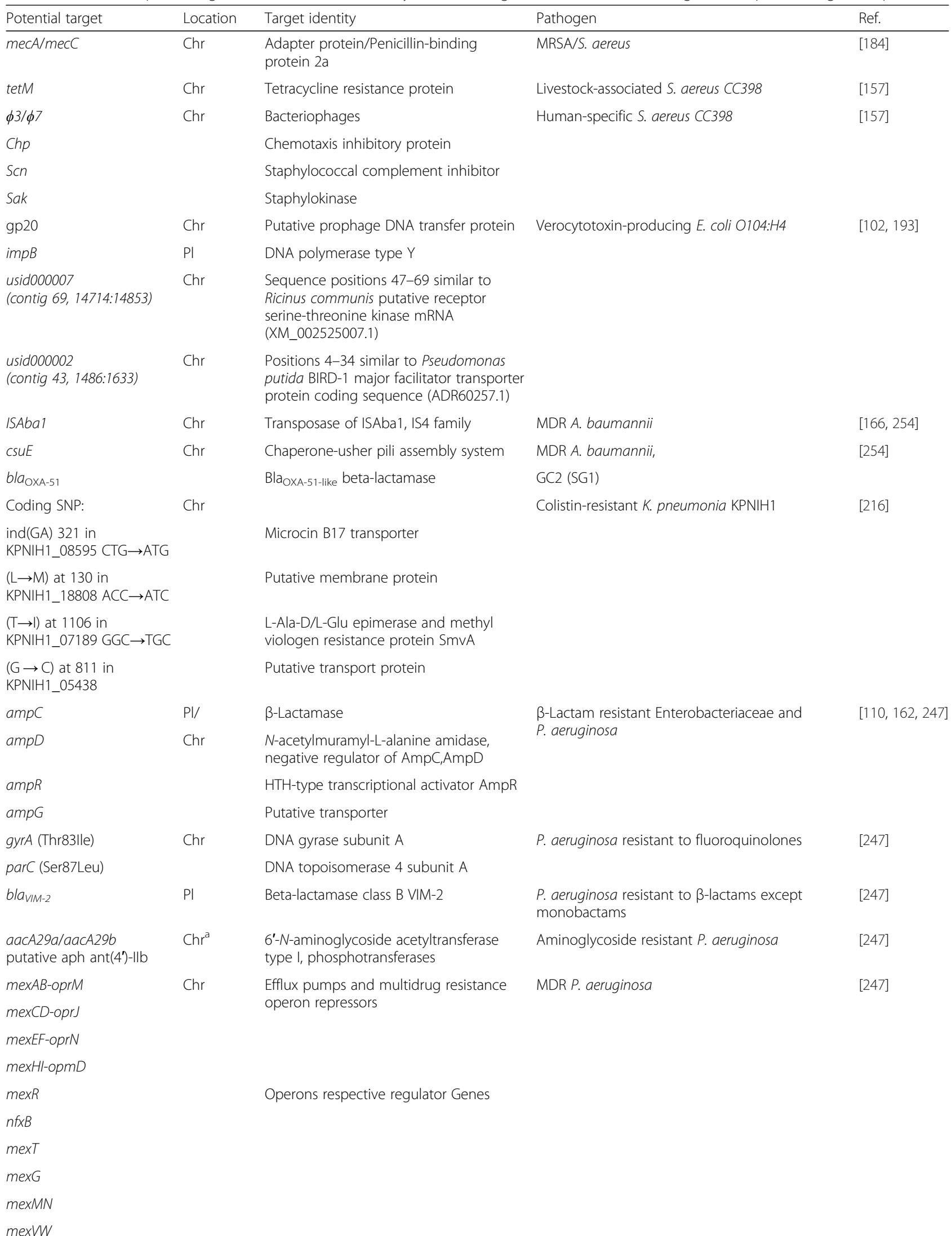


Table 2 List of the putative genetic markers obtained by WGS for diagnostics of the bacterial agents of epidemiological importance (Continued)

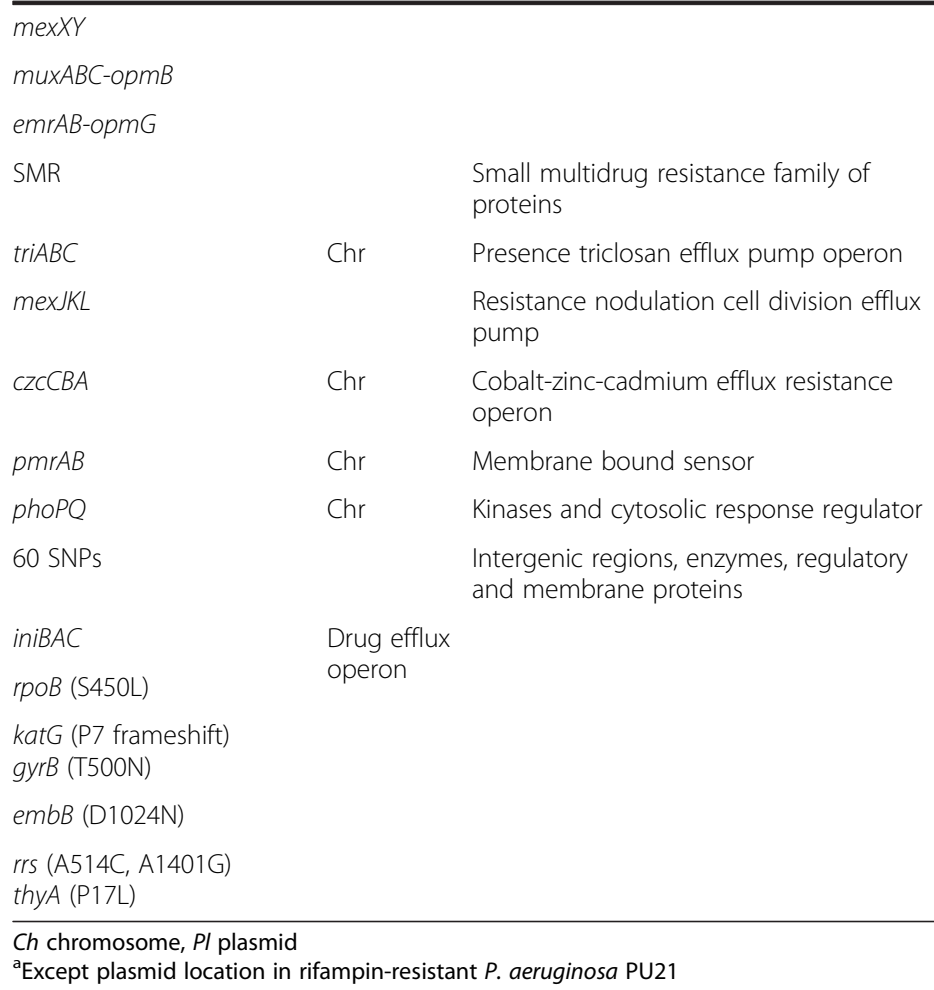

testing. The innovative WGS technologies can be successfully applied for clinical trials to evaluate the potential antibacterial targets, inhibitors, efficacy of the drugs, and therapeutic alteration of the microbiome in a range of conditions for rational structure-based drug design in a single step (Fig. 2). An important point is that the WGS strategies of screening for novel "drugable" classes of molecules and targets are easily compatible with natural product discovery programs and existing phenotypic high-throughput screening and thus can significantly improve and speed up current practical outcomes [13, 35, 108, 148].

Inhibitor-first approach (reverse pharmacology) The inhibitor-first strategies are more effective than targetdriven ones [220] and remain the main approaches of choice for delivering antibacterial drugs to the clinics [20]. WGS screening can be applied to identify molecules that inhibit bacterial growth by diverse mechanisms, including those that engage multiple targets. An extensive list of the antimicrobial drugs discovered recently via WGS data is presented by Deane and Mitchell [44]. As a whole, most of these natural products are essential components of the metabolic pathways for the vitamin biosynthetic (B1, B3, B9), fatty acid synthesis (FASII), and isoprenoid biosynthesis (fosmidomycin, 6-fluoromevalonate). Genomic analysis can also help to reveal genes or gene clusters that are important for biosynthesis of natural antibacterial inhibitors but remain silent under laboratory growth conditions or in the environment. For example, induced expression analysis of environmental DNA gene clusters revealed that tetarimycin $\mathrm{A}$, a new class of tetracylic MRSA-active antibiotic isolated from the culture broth extract of Streptomyces albus, was encoded by the tam gene cluster [119]. Screening of libraries of complete genomes of the soil microbial community extended the potential value of this compound having revealed numerous silent tam-like gene clusters that possibly encode other members of tetarimycin family in the environment [119]. Streptomyces coelicolor is another example. Before completion of its genome sequence, only three gene clusters coding natural products had been identified for actinorhodin [154], prodiginine [58], and lipopeptide calciumdependent antibiotic [32]. WGS revealed that S. coelicolor carries clusters of new "cryptic" genes which have a potential for biosynthesis of 29 structurally complex unknown natural products that can be potentially applied as antimicrobials [38].

Target-driven approaches Knowledge of the threedimensional structure of the drugable targets can also be used for generating or discovering novel-specific inhibitors. Traditionally, a target-driven approach starts from high- 


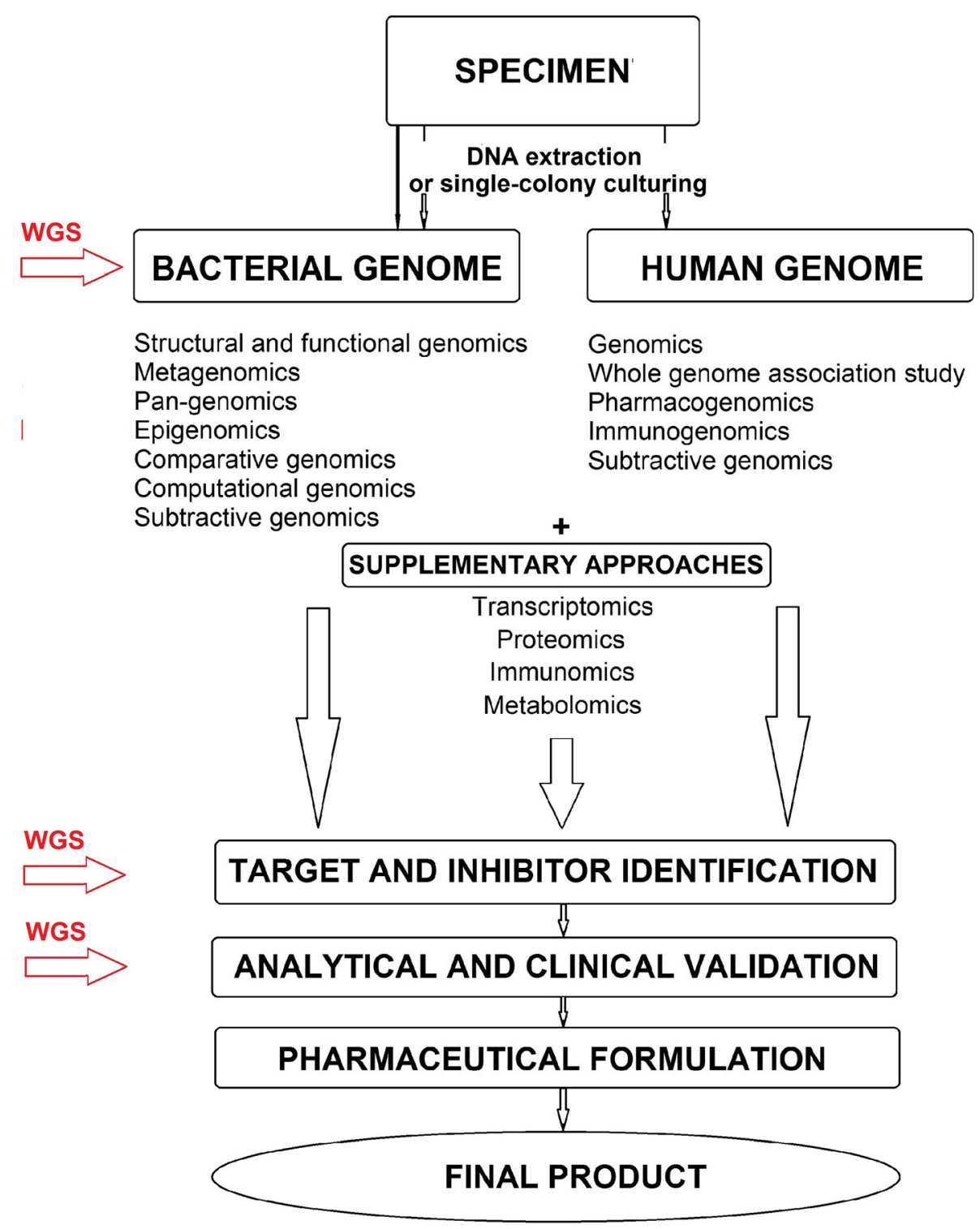

Fig 2 Schematic procedure of drug development based on genomic data, obtained by WGS

throughput screening for inhibitors of a purified target protein. Unfortunately, most inhibitors identified in highthroughput screenings are not active against live bacteria or are not safe for use in humans [185]. WGS can contribute to the de bene esse discovery of the candidate genetic targets for both inhibitors of known or entirely novel mechanism of action (MOAs) before conventional screening for DR bacteria. Determination of resistance mutations in the targets by WGS can also be used for evaluation and estimation of the resistance of the bacterial population to the drug. The target-driven WGS approach was first applied for target FabF, an enzyme required for fatty acid biosynthesis (FAS) [122]. Four novel type II FAS (FASII) inhibitors with broad spectrum activity against Gram-positive bacteria, including MRSA, Platensimcyin, Plantencin, BABX, and Phomallenic acid C, were developed using this method [19, 122, 207, 244, 259]. Recently, several novel antibiotics, fasamycin A and B, with specific activity against FabF of MRSA and vancomycin-resistant Enterococcus faecalis were also revealed [61].

Studies performed on a collection of several human pathogens suggested that on the average, about $15-25 \%$ of all genes in a genome are potential drugable targets $[33,164,238]$. These studies concluded that the potential targets are regions whose products/structures are important for bacterial growth and survival under a variety of conditions (e.g., the synthetic machinery of the bacterial membranes, peptidoglycans, lipopolysaccharides, the DNA replication machinery, the nucleic acid synthesis pathway, and ribosomal structures) but do not prevent growth in 
animals or humans [243]. Thus, WGS screening identified mutations correlating with mycobacterial MDR in genes involved in respiration, fatty acid biosynthesis kasA [137], qcrB [1, 187], protein synthesis aspS [89, 107], protein secretion eccB3 [107], polyketide biosynthesis pks13 [107, 246], mycolic acid transport mmpL3 [197], and arabinogalactan synthesis dprE1 [34]. Another study of pathogenic bacteria revealed other candidate structures e.g., amino-acyl-tRNA binding site (A-site) and components of the 2-C-methyl-D-erythritol 4-phosphate (MEP) pathway which are also potential targets for the development of new antibiotics for various emerging pathogens $[105,186]$. Screening of bacterial genomes for the presence of this ligand can be used for the development of drugs which are active against a wide range of pathogens $[64,105,236]$.

However, the target-driven method has some limitations. For example, it can only be applied if resistant strains were obtained. Furthermore, it is important to remember that the target-mechanism identified (such as efflux pump expression, chemical inactivation, or malfunction of transforming an inactive prodrug into the active derivative) can be just one of the existing mechanisms by which mutations can impart resistance. Presence of several candidate targets, which belong to the same protein family with conserved inhibitor binding, can also complicate their further interpretation and evaluation by overexpression analyses [21, 234]. In addition, mutations in nonessential genes can also significantly modulate the main target's structure or functionality resulting in partial activity of antibiotics [147].

Clinical trials WGS can be applied to design clinical trials more efficiently. First, it can be used at the early phases of drug development to screen a phylogenetically diverse collection of the pathogens for the presence and variability of the candidate drug's target. Such analysis will prove that this target and its variations are valid and important for all species and lineages of the pathogenic genus and, thus, reduce the chance to miss any resistant strains [128].

Second, WGS can be used to determine drug's MOA directly. Although it is not mandatory to define an antibacterial compound's MOA for use in humans, this knowledge can help developing novel drugs for a broad range of bacteria and evaluate their toxicity and specificity a priori. Knowledge of MOAs will also reduce time for clinical trials of chemically redundant putative compounds that fail for the same mechanistic reasons. Further, identification of the MOA and candidate targets can give another chance to existing antibiotics. For example, bottromycins, antibacterial peptides with activity against several Gram-positive bacteria and mycoplasma, were discovered more than 50 years ago. Later on, it was revealed that these peptides' binding
A-site on the $50 \mathrm{~S}$ ribosome lead to the inhibition of protein synthesis and thus can become a novel promising class of antibiotics applied against vancomycin-resistant Enterococci (VRE) and MRSA [105].

Third, knowledge about resistance mechanisms at the genetic level is very important for determining and avoiding cross-resistance of the pathogen, when multiple antibiotics should be applied for treatment [167]. Fourth, sequencing of pathogens during clinical trials has the potential to distinguish exogenous re-infection from the primary infection. This is crucial in order to assess the efficacy of study drugs and estimate the therapeutic effect in a range of conditions $[22,23,127,237]$.

However, as the field of the genomic drug and target discovery moves forward, the problem stemming from the elucidation of novel unknown classes of gene products remains significant. It is important to remember that no single method is sufficient to define the MOAs of most antibacterial drugs, but a complex approach is required [27]. The detailed genomic analysis of the human pathogens (microbiota), as well as gene expression and drug susceptibility analyses of pathogens, together with powerful bioinformatics tools, can provide new applications to "old" drugs and invigorate the discovery process for novel antibiotics [43, 191]. In this regard, the discovery of the novel anti-TB inhibitors (e.g., bedaquiline, pyridomycin, SQ109, BM212, adamantyl ureas, benzimidazole, BTZ, TCA, and imidazol[1,2-a]pyridine related derivatives) succeeded by a combination of high-throughput screening and WGS analysis of spontaneous resistant mutants for target identification, combined with modern bioinformatics tools $[8,97,183]$. Zomer and colleagues also demonstrated that the combination of high-density transposon mutagenesis, WGS, and integrative genomics has a great potential for reliable identification of potential drug targets in Streptococcus pneumoniae, Haemophilus influenzae, and Moraxella catarrhalis [164]. This complex analysis predicted 249 potential drug targets, 67 of which were targets for $75 \mathrm{FDA}$-approved antimicrobials and 35 other researched small molecule inhibitors.

\section{Conclusions}

What does the future hold for WGS? Herein, we showed that WGS may be well poised to make a decisive impact on the study and control of MDR in pathogenic bacteria (Table 1) [126]. However, although not reviewed here, studies have shown that WGS can also contribute to the investigation of various pathogenic and beneficial resistant microorganisms: bacteria [70, 155], fungi (Candida spp., Cryptococcus neoformans, Pneumocystis spp., and Aspergillus spp.) [208], and viruses (HIV virus, hepatitis $B$, hepatitis $C$, influenza, herpes viruses) $[144,255]$. Of course, we should not neglect the potential importance of the human genome sequencing and investigation of 
host-pathogen interaction for patient management and drug development. The combination of the MDR bacterial and human WGS data together with genome-wide association studies and expanding computational capacity offers new power to elucidate host immune traits and genetic factors/variants contributing/altering to susceptibility to MDR bacterial diseases in humans [28]. Such studies have been extensively published $[4,28,65,226]$.

Technical development promises portable, single-molecule, long-read, and user-friendly sequencing platforms, with high functionality and cost-effectiveness. These novel technologies will provide unprecedented opportunities for clinics and public health and may soon change our lifestyle. However, there are still many difficulties to overcome. There is a call for conceptual change of rational sampling strategies, experiment design, and data analysis management. The proper collection, processing, and storage of biological specimens are also critical. The pathway from sequencing the DNA of a specimen to a clinical treatment plan of the patient depends on the integration of each sample's genomic information with databases that contain known genotype-phenotype correlations and clinical associations obtained from large sample sets. Well curated and regularly updated databases of resistance genotype-phenotype links of MDR pathogens and computational tools to interrogate the ever-increasing information in a robust way are urgently required for MDR pathogen identification and control as well as for novel drug development. These improvements will help to solve many of the critical issues of WGS applicability for both public health and scientific purposes.

\begin{abstract}
Abbreviations
AGST: antigen gene sequence typing; A-site: amino-acyl-tRNA binding site; BSI: bloodstream infection; CA-UTI: catheter-associated urinary tract infection; CF: cystic fibrosis; Cl: confidence interval; DIPs: deletion/insertion polymorphisms; DR: drug resistance (or resistant); FAS: fatty acid synthesis; HAP: hospital-acquired pneumonia; IGS: individual genome sequencing; MALDI-TOF MS: matrix-assisted laser desorption ionization-time of flight mass spectrometry; MDR: multidrug resistance (or resistant); MGEs: mobile genetic elements; MIRU-VNTR: mycobacterial interspersed repetitive unit variable number tandem repeat genotyping; MLST: multilocus sequencing typing; MRSA: meticillin-resistant Staphylococcus aureus; MSSA: methicillin-sensitive S. aureus; NGS: next-generation sequencing; PBP: penicillin-binding protein; SCC: staphylococcal cassette chromosome; SNP: single-nucleotide polymorphism (a single nucleotide aberration which can be found in more than at least $1 \%$ members of bacterial population); SNV: single-nucleotide variation (a single nucleotide aberration without any limitations of frequency e.g., was not validated for population and can be found in one individual); SSI: surgical-site infection; SV: structural variations (large genomic variations, including insertions, deletions, inversions, translocations, and duplications); TB: tuberculosis; UTT: Urinary tract infection; VAP: ventilator-associated pneumonia; WGS: whole-genome sequencing; WSI: wound stream infection.
\end{abstract}

\section{Competing interests}

The authors declare that they have no competing interests.

\section{Authors' contributions}

NVP and MAR conceived and drafted the study. NMM and AFT contributed knowledge and expertise and helped in the writings. NVP and NMM wrote the manuscript. All authors read and approved the final version of the manuscript.

\section{Acknowledgements}

We thank $V$ Punina and $V$ Kadnikov for critically reading this manuscript. We are grateful for past and present support from A.N. Bach Institute of Biochemistry of Russia Academy of Science, Moscow, Russia. This work was supported by Russian Foundation for Humanities (RFH), № 15-36-01024, DOD grant PC094628, and NIH grant 8 P20 GM103518 (to NMM).

\section{Author details}

'Bach Institute of Biochemistry, Russian Academy of Science, Moscow 119071, Russia. ${ }^{2}$ Tulane University School of Public Health and Tropical Medicine, New Orleans, LA 70112, USA. ${ }^{3}$ The Federal State Unitary Enterprise All-Russia Research Institute of Automatics, Moscow 127055, Russia.

Received: 24 April 2015 Accepted: 3 July 2015

Published online: 05 August 2015

\section{References}

1. Abrahams KA, Cox JA, Spivey VL, Loman NJ, Pallen MJ, Constantinidou C, et al. Identification of novel imidazo[1,2-a]pyridine inhibitors targeting M. tuberculosis QcrB. PLoS One. 2012. doi:10.1371/journal.pone.0052951.

2. Adams MD, Goglin K, Molyneaux N, Hujer KM, Lavender H, Jamison JJ, et al. Comparative genome sequence analysis of multidrug-resistant Acinetobacter baumannii. J Bacteriol. 2008. doi:10.1128/JB.00834-08.

3. Adey A, Morrison HG, Xun X, Kitzman JO, Turner EH, Stackhouse B, et al. Rapid, low-input, low-bias construction of shotgun fragment libraries by high-density in vitro transposition. Genome Biol. 2010. doi:10.1186/gb-201011-12-r119.

4. Ahn S-H, Deshmukh H, Johnson N, Cowell LG, Rude TH, Scott WK, et al. Two genes on $\mathrm{A} / \mathrm{J}$ chromosome 18 are associated with susceptibility to Staphylococcus aureus infection by combined microarray and QTL analyses. PLoS Pathog. 2010;6(9), e1001088. doi:10.1371/journal.ppat.1001088.

5. Albuquerque P, Mendes MV, Santos CL, Moradas-Ferreira P, Tavares FF. DNA signature-based approaches for bacterial detection and identification. Sci Total Environ. 2008;26:3641-51.

6. Allard MW, Luo Y, Strain E, Li C, Keys CE, Son I, et al. High resolution clustering of Salmonella enterica serovar Montevideo strains using a next-generation sequencing approach. BMC Genomics. 2012;13:32.

7. Andersson P, Klein M, Lilliebridge RA, Giffard PM. Sequences of multiple bacterial genomes and a Chlamydia trachomatis genotype from direct sequencing of DNA derived from a vaginal swab diagnostic specimen. Clin Microbiol Infect. 2013. doi:10.1111/1469-0691.12237.

8. Andries K, Verhasselt P, Guillemont J, Göhlmann HW, Neefs JM, Winkler H, et al. A diarylquinoline drug active on the ATP synthase of Mycobacterium tuberculosis. Science. 2005;307(5707):223-7.

9. Anthonisen IL, Sunde M, Steinum TM, Sidhu MS, Sorum H. Organization of the antiseptic resistance gene qacA and Tn552-related beta-lactamase genes in multidrug- resistant Staphylococcus haemolyticus strains of animal and human origins. Antimicrob Agents Chemother. 2002;46(11):3606-12.

10. Aragon TJ, Reingold A. Epidemiologic concepts for the prevention and control of infectious diseases. In Baker S, Hanage WP, Holt KE, editors Navigating the future of bacterial molecular epidemiology. Curr Opin Microbiol. 2010;13:640-5.

11. Baker S, Holt KE, Clements AC, Karkey A, Arjyal A, Boni MF, et al. Combined high-resolution genotyping and geospatial analysis reveals modes of endemic urban typhoid fever transmission. Open Biol. 2011. doi:10.1098/rsob.110008.

12. Batra R, Cooper BS, Whiteley C, Patel AK, Wyncoll D, Edgeworth JD. Efficacy and limitation of a chlorhexidine-based decolonization strategy in preventing transmission of methicillin-resistant Staphylococcus aureus in an intensive care unit. Clin Infect Dis. 2010;50:210-7.

13. Bax BD, Chan PF, Eggleston DS, Fosberry A, Gentry DR, Gorrec F, et al. Type IIA topoisomerase inhibition by a new class of antibacterial agents. Nature. 2010;466:935-40.

14. Ben Zakour NL, Venturini C, Beatson SA, Walker MJ. Analysis of a Streptococcus pyogenes puerperal sepsis cluster by use of whole-genome sequencing. J Clin Microbiol. 2012;50(7):2224-8

15. Beres SB, Carroll RK, Shea PR, Sitkiewicz I, Martinez-Gutierrez JC, Low DE, et al. Molecular complexity of successive bacterial epidemics convoluted by comparative pathogenomics. Proc Natl Acad Sci U S A. 2010;107:4371-6. 
16. Berger-Bachi B, Dyke K, Gregory P. Resistance to beta-lactam antibiotics. Resistance not mediated by beta-lactamase (methicillin resistance). In: Crossley KB, Archer GL, editors. The staphylococci in human disease. New York, NY: Churchill Livingstone; 1997. p. 139-57.

17. Berger-Bachi $B$, Rohrer $S$. Factors influencing methicillin resistance in staphylococci. Arch Microbiol. 2002;178:165-71.

18. Bologa CG, Ursu O, Oprea TI, Melançon CE, Tegos GP. Emerging trends in the discovery of natural product antibacterials. Curr Opin Pharmacol. 2013;13(5):678-87.

19. Bourgogne A, Garsin DA, Qin X, Singh KV, Sillanpaa J, Yerrapragada S, et al. Large scale variation in Enterococcus faecalis illustrated by the genome analysis of strain OG1RF. Genome Bio. 2008. doi:10.1186/gb-2008-9-7-r110.

20. Brotz-Oesterhelt $H$, Sass P. Postgenomic strategies in antibacterial drug discovery. Future Microbiol. 2010;5:1553-79.

21. Brown AK, Taylor RC, Bhatt A, Futterer K, Besra GS. Platensimycin activity against mycobacterial b-ketoacyl-ACP synthases. PLoS One. 2010. doi:10.1371/journal.pone.0006306.

22. Bryant JM, Harris SR, Parkhill J, Dawson R, Diacon AH, van Helden P, et al. Whole-genome sequencing to establish relapse or re-infection with Mycobacterium tuberculosis: a retrospective observational study. The Lancet Respiratory Medicine. 2013;1(10):786-92.

23. Bryant JM, Schurch AC, van Deutekom H, Harris SR, de Beer JL, de Jager V, et al. Inferring patient to patient transmission of Mycobacterium tuberculosis from whole genome sequencing data. BMC Infect Dis. 2013;13:110.

24. Caskey CT. Using genetic diagnosis to determine individual therapeutic utility. Annu Rev Med. 2010;61:1-15.

25. Cavanagh JP, Hjerde E, Holden MT, Kahlke T, Klingenberg C, Flægstad T, et al. Whole-genome sequencing reveals clonal expansion of multiresistant Staphylococcus haemolyticus in European hospitals. J Antimicrob Chemother. 2014;69(11):2920-7.

26. Centers for Disease Control and Prevention, US Department of Health and Human Services. Antibiotic resistance threats in the United States, 2013. Report. 2013. http://www.cdc.gov/drugresistance/threat-report-2013/. Accessed 23 April 2013.

27. Chakraborty S, Gruber T, Barry CE, Boshoff HI, Rhee KY. Para-aminosalicylic acid acts as an alternative substrate of folate metabolism in Mycobacterium tuberculosis. Science. 2013;339:88-91.

28. Chapman SJ, Hill AV. Human genetic susceptibility to infectious disease. Nature Rev Genet. 2012:13:175-88.

29. Chernyaeva EN, Shulgina MV, Rotkevich MS, Dobrynin PV, Simonov SA, Shitikov EA, et al. Genome-wide Mycobacterium tuberculosis variation (GMTV) database: a new tool for integrating sequence variations and epidemiology. BMC Genomics. 2014;15:308.

30. Chin CS, Sorenson J, Harris JB, Robins WP, Charles RC, Jean-Charles RR, et al. The origin of the Haitian cholera outbreak strain. N Engl J Med. 2011;364(1):33-42

31. Chiu CH, Tang P, Chu C, Hu S, Bao Q, Yu J, et al. The genome sequence of Salmonella enterica serovar Choleraesuis, a highly invasive and resistant zoonotic pathogen. Nucleic Acids Res. 2005;33(5):1690-8.

32. Chong PP, Podmore SM, Kieser HM, Redenbach M, Turgay K, Marahiel M, et al. Physical identification of a chromosomal locus encoding biosynthetic genes for the lipopeptide calcium-dependent antibiotic (CDA) of Streptomyces coelicolor A3(2). Microbiology. 1998;144(1):193-9.

33. Christen B, Abeliuk E, Collier JM, Kalogeraki VS, Passarelli B, Coller JA, et al. The essential genome of a bacterium. Mol Syst Biol. 2011;7:528.

34. Christophe $T$, Jackson M, Jeon HK, Fenistein D, Contreras-Dominguez M, Kim J, et al. High content screening identifies decaprenyl-phosphoribose 2 ' epimerase as a target for intracellular antimycobacterial inhibitors. PLoS Pathog. 2009. doi:10.1371/journal.ppat.1000645.

35. Clark RB, He M, Fyfe C, Lofland D, O'Brien WJ, Plamondon L, et al. 8-Azatetracyclines: synthesis and evaluation of a novel class of tetracycline antibacterial agents. J Med Chem. 2011;54:1511-28.

36. Cleven BEE, Palka-Santini M, Gielen J, Meembor S, Krönke M, Krut O. Identification and characterization of bacterial pathogens causing bloodstream infections by DNA microarray. J Clin Microbiol. 2006;44(7):2389-97.

37. Cooper BS, Kypraios T, Batra R, Wyncoll D, Tosas O, Edgeworth JD. Quantifying type-specific reproduction numbers for nosocomial pathogens: evidence for heightened transmission of an Asian sequence type 239 MRSA clone. PLoS Comput Biol. 2012. doi:10.1371/journal.pcbi.1002454.
38. Craney A, Ahmed S, Nodwell J. Towards a new science of secondary metabolism. J Antibiot. 2013;66:387-400.

39. Croxatto A, Prodhom G, Greub G. Applications of MALDI-TOF mass spectrometry in clinical diagnostic microbiology. FEMS Microbiol Rev. 2012;36:380-407.

40. Cunningham SA, Sloan LM, Nyre LM, Vetter EA, Mandrekar J, Patel R. Three-hour molecular detection of Campylobacter, Salmonella, Yersinia, and Shigella species in feces with accuracy as high as that of culture. J Clin Microbiol. 2010;48:2929-33.

41. Darch SE, McNally A, Harrison F, Corander J, Barr HL, Paszkiewicz K, et al. Recombination is a key driver of genomic and phenotypic diversity in a Pseudomonas aeruginosa population during cystic fibrosis infection. Scientific Reports. 2015:5:7649.

42. Davies SC, Fowler T, Watson J, Livermore DM, Walker D. Annual report of the chief medical. The Lancet. 2013;381(9878):1606-9.

43. de Jong A, van Hijum SA, Bijlsma JJ, Kok J, Kuipers OP. BAGEL: a web-based bacteriocin genome mining tool. Nucleic Acids Res. 2006;34:273-9.

44. Deane CD, Mitchell DA. Lessons learned from the transformation of natural product discovery to a genome-driven endeavor. J Ind Microbiol Biotechnol. 2014;41(2):315-31.

45. Dettman JR, Rodrigue N, Aaron SD, Kassen R. Evolutionary genomics of epidemic and nonepidemic strains of Pseudomonas aeruginosa. Proc Natl Acad Sci U S A. 2013;110(52):21065-70.

46. Didelot X, Bowden R, Wilson DJ, Peto TE, Crook DW. Transforming clinical microbiology with bacterial genome sequencing. Nature Rev Genet. 2012;13:601-12.

47. Diene SM, Merhej V, Henry M, El Filali A, Roux V, Robert C, et al. The rhizome of the multidrug-resistant Enterobacter aerogenes genome reveals how new "killer bugs" are created because of a sympatric lifestyle. Mol Biol Evol. 2013;30(2):369-83.

48. Diene SM, Rolain JM. Investigation of antibiotic resistance in the genomic era of multidrug-resistant Gram-negative bacilli, especially Enterobacteriaceae, Pseudomonas and Acinetobacter. Expert Rev Anti Infect Ther. 2013;11:277-96.

49. Donadio S, Maffioli S, Monciardini P, Sosio M, Jabes D. Antibiotic discovery in the twenty-first century: current trends and future perspectives. J Antibiot (Tokyo). 2010;63(8):423-30.

50. Dougherty TJ, Barrett JF, Pucci MJ. Microbial genomics and novel antibiotic discovery: new technology to search for new drugs. Curr Pharm Des. 2002;8:1119-35.

51. Edwards JS, Ibarra RU, Palsson BO. In silico predictions of Escherichia coli metabolic capabilities are consistent with experimental data. Nat Biotechnol. 2001:19(2):125-30

52. Eldholm V, Norheim G, von der Lippe B, Kinander W, Dahle UR, Caugant DA et al. Evolution of extensively drug-resistant Mycobacterium tuberculosis from a susceptible ancestor in a single patient. Genome Biol. 2014;15(11):490.

53. Eyre DW, Golubchik T, Gordon NC, Bowden R, Piazza P, Batty EM, et al. A pilot study of rapid benchtop sequencing of Staphylococcus aureus and Clostridium difficile for outbreak detection and surveillance. BMJ Open. 2012. doi:10.1136/bmjopen-2012-001124.

54. Ezewudo MN, Joseph SJ, Castillo-Ramirez S, Dean D, Del Rio C, Didelot X, et al. Population structure of Neisseria gonorrhoeae based on whole genome data and its relationship with antibiotic resistance. PeerJ. 2015. doi:10.7717/peerj.806.

55. Falagas ME, Karageorgopoulos DE, Leptidis J, Korbila IP. MRSA in Africa: filling the global map of antimicrobial resistance. PLoS One. 2013. doi:10.1371/journal.pone.0068024.

56. Fani F, Leprohon P, Zhanel GG, Bergeron MG, Ouellette M. Genomic analyses of DNA transformation and penicillin resistance in Streptococcus pneumoniae clinical isolates. Antimicrob Agents Chemother. 2014;58(3):1397-403.

57. Feavers IM, Gray SJ, Urwin R, Russell JE, Bygraves JA, Kaczmarski EB, et al. Multilocus sequence typing and antigen gene sequencing in the investigation of a meningococcal disease outbreak. J Clin Microbiol. 1999;37(12):3883-7.

58. Feitelson JS, Malpartida F, Hopwood DA. Genetic and biochemical characterization of the red gene cluster of Streptomyces coelicolor A3(2). J Gen Microbiol. 1985;131(9):2431-41.

59. Felmingham $\mathrm{D}$. The need for antimicrobial resistance surveillance. J Antimicrob Chemother. 2002;50 Suppl S1:1-7.

60. Felmingham D. Evolving resistance patterns in community-acquired respiratory tract pathogens: first results from the PROTEKT global surveillance 
study. Prospective resistant organism tracking and epidemiology for the ketolide telithromycin. J Infect. 2002;44 Suppl A:3-10.

61. Feng Z, Chakraborty D, Dewell SB, Reddy BV, Brady SF. Environmental DNA-encoded antibiotics fasamycin A and B inhibit FabF in type II fatty-acid biosynthesis. J Am Chem Soc. 2012;134:29817.

62. Feng J, Lupien A, Gingras H, Wasserscheid J, Dewar K, Légaré D, et al. Genome sequencing of linezolid-resistant Streptococcus pneumoniae mutants reveals novel mechanisms of resistance. Genome Res. 2009:19:1214-23.

63. Fernandez-Alarcon C, Singer RS, Johnson TJ. Comparative genomics of multidrug resistance-encoding IncA/C plasmids from commensal and pathogenic Escherichia coli from multiple animal sources. PLOS ONE. 2011. doi:10.1371/journal.pone.0023415.

64. Fischbach MA, Walsh CT. Antibiotics for emerging pathogens. Science. 2009:325:1089-93.

65. Flores J, Okhuysen PC. Genetics of susceptibility to infection with enteric pathogens. Curr Opin Infect Dis. 2009;22(5):471-6.

66. Fluit ADC, Visser MR, Schmitz FJ. Molecular detection of antimicrobial resistance. Clin Microbiol Rev. 2011;14(4):836-71.

67. Ford CB, Lin PL, Chase MR, Shah RR, lartchouk O, Galagan J, et al. Use of whole genome sequencing to estimate the mutation rate of Mycobacterium tuberculosis during latent infection. Nat Genet. 2011;43(5):482-6.

68. Fournier PE, Drancourt M, Colson P, Rolain JM, La Scola B, Raoult D. Modern clinical microbiology: new challenges and solutions. Nat Rev Microbiol. 2013;11(8):574-85.

69. Fournier PE, Drancourt M, Raoult D. Bacterial genome sequencing and its use in infectious diseases. Lancet Infect Dis. 2007;7:711-23.

70. Fournier PE, Dubourg G, Raoult D. Clinical detection and characterization of bacterial pathogens in the genomics era. Genome Medicine. 2014;6(11):114.

71. Fournier PE, Vallenet D, Barbe V, Audic S, Ogata H, Poirel L, et al. Comparative genomics of multidrug resistance in Acinetobacter baumannii. PLoS Genet. 2006. doi:10.1371/journal.pgen.0020007.

72. Frank C, Werber D, Cramer JP, Askar M, Faber M, der Heiden M, et al. Epidemic profile of Shiga-toxin-producing Escherichia coli O104:H4 outbreak in Germany. N Engl J Med. 2011;365(19):1771-80.

73. Fricke WF, Welch TJ, McDermott PF, Mammel MK, LeClerc JE, White DG, et al. Comparative genomics of the IncA/C multidrug resistance plasmid family. J Bacteriol. 2009;191:4750-7.

74. Fricke WF, Wright MS, Lindell AH, Harkins DM, Baker-Austin C, Ravel J, et al. Insights into the environmental resistance gene pool from the genome sequence of the multidrug-resistant environmental isolate Escherichia coli SMS-3-5. J Bacteriol. 2008:190(20):6779-94.

75. Fridkin SK, Hageman JC, Morrison M. Meticillin-resistant Staphylococcus aureus disease in three communities. N Engl J Med. 2005;352:1436-44.

76. Garcia-Alvarez L. Meticillin-resistant Staphylococcus aureus with a novel mecA homologue in human and bovine populations in the UK and Denmark: a descriptive study. Lancet Infect Dis. 2011;11:595-603.

77. Gardy JL, Johnston JC, Ho Sui SJ, Cook VJ, Shah L, Brodkin E, et al. Whole-genome sequencing and social-network analysis of a tuberculosis outbreak. N Engl J Med. 2011;364:730-9.

78. Gilmore A, Jones G, Barker M, Soltanpoor N, Stuart JM. Meningococcal disease at the University of Southampton: outbreak investigation. Epidemiol Infect. 1999:123(2):185-92.

79. Global Burden Diseases (GBD) 2013 Mortality and Causes of Death Collaborators. Global, regional, and national age-sex specific all-cause and cause-specific mortality for 240 causes of death, 1990-2013: a systematic analysis for the Global Burden of Disease Study 2013. Lancet. 2015;385(9963):117-71.

80. Gonzalez BE, Rueda AM, Shelburne SA, Musher DM, Hamill RJ, Hulten KG. Community-associated strains of meticillin-resistant Staphylococccus aureus as the cause of healthcare-associated infection. Infect Control Hosp Epidemiol. 2006;27:1051-6.

81. Gooderham WJ, Hancock REW. Regulation of virulence and antibiotic resistance by two-component regulatory systems in Pseudomonas aeruginosa. FEMS Microbiol Rev. 2009;33:279-94.

82. Gordon NC, Price JR, Cole K, Everitt R, Morgan M, Finney J, et al. Prediction of Staphylococcus aureus antimicrobial resistance by whole-genome sequencing. J Clin Microbiol. 2014;52(4):1182-91.

83. Grad YH, Kirkcaldy RD, Trees D, Dordel J, Harris SR, Goldstein E, et al. Genomic epidemiology of Neisseria gonorrhoeae with reduced susceptibility to cefixime in the USA: a retrospective observational study. Lancet Infect Dis. 2014;14(3):220-6.
84. Grad YH, Lipsitch M, Feldgarden M, Arachchi HM, Cerqueira GC, Fitzgerald M, et al. Genomic epidemiology of the Escherichia coli O104:H4 outbreaks in Europe, 2011. Proc Natl Acad Sci U S A. 2012;109(8):3065-70.

85. Green S, Studholme DJ, Laue BE, Dorati F, Lovell H, Arnold D, et al. Comparative genome analysis provides insights into the evolution and adaptation of Pseudomonas syringae pv. aesculi on Aesculus hippocastanum. PLoS One. 2010. doi:10.1371/journal.pone.0010224.

86. Grundmann $\mathrm{H}$. Towards a global antibiotic resistance surveillance system: a primer for a roadmap. Ups J Med Sci. 2014;119:87-95.

87. Guard J, Morales CA, Fedorka-Cray P, Gast RK. Single nucleotide polymorphisms that differentiate two populations of Salmonella enteritidis within phage type. BMC Res Notes. 2011;4:369.

88. Guerra-Assunção JA, Houben RM, Crampin AC, Mzembe T, Mallard K, Coll F, et al. Recurrence due to relapse or reinfection with Mycobacterium tuberculosis: a wholegenome sequencing approach in a large, population-based cohort with a high HIV infection prevalence and active follow-up. J Infect Dis. 2015;211(7):1154-63.

89. Gurcha SS, Usha V, Cox JAG, Fütterer K, Abrahams KA, Bhatt A, et al. Biochemical and structural characterization of mycobacterial aspartyl-tRNA synthetase AspS, a promising TB drug target. PLoS One. 2014. doi:10.1371/journal.pone.0113568.

90. Halachev MR, Chan JZ, Constantinidou Cl, Cumley N, Bradley C, Smith-Banks M, et al. Genomic epidemiology of a protracted hospital outbreak caused by multidrug-resistant Acinetobacter baumannii in Birmingham. England Genome Med. 2014;6(11):70

91. Hall RM. Salmonella genomic islands and antibiotic resistance in Salmonella enterica. Future Microbiol. 2010;5(10):1525-38.

92. Hamburg MA, Collins FS. The path to personalized medicine. N Engl J Med. 2010;363:301-4.

93. Harris SR, Cartwright EJ, Torok ME, Holden MT, Brown NM, Ogilyy-Stuart AL, et al. Whole-genome sequencing for analysis of an outbreak of meticillin-resistant Staphylococcus aureus: a descriptive study. Lancet Infect Dis. 2013;13:130-6.

94. Harris SR, Feil EJ, Holden MT, Quail MA, Nickerson EK, Chantratita N, et al. Evolution of MRSA during hospital transmission and intercontinental spread. Science. 2011;327:469-74.

95. Harris SR, Feil EJ, Holden MT. Evolution of MRSA during hospital transmission and intercontinental spread. Science. 2010;327:469-74.

96. Harris SR, Török ME, Cartwright EJ, Quail MA, Peacock SJ, Parkhill J. Read and assembly metrics inconsequential for clinical utility of whole-genome sequencing in mapping outbreaks. Nat Biotechnol. 2013;31:592-4.

97. Hartkoorn RC, Sala C, Neres J, Pojer F, Magnet S, Mukherjee R, et al. Towards a new tuberculosis drug: pyridomycin—nature's isoniazid. EMBO Mol Med. 2012:4:1032-42.

98. Hasman H, Saputra D, Sicheritz-Ponten T, Lund O, Svendsen CA, Frimodt-Møller $\mathrm{N}$, et al. Rapid whole-genome sequencing for detection and characterization of microorganisms directly from clinical samples. J Clin Microbiol. 2014;52(1):139-46.

99. Hassan M, Kjos M, Nes IF, Diep DB, Lotfipour F. Natural antimicrobial peptides from bacteria: characteristics and potential applications to fight against antibiotic resistance. J Appl Microbiol. 2012;113(4):723-36.

100. Hazen TH, Zhao L, Boutin MA, Stancil A, Robinson G, Harris AD, et al. Comparative genomics of an IncA/C multidrug resistance plasmid from Escherichia coli and Klebsiella isolates from intensive care unit patients and the utility of whole-genome sequencing in health care settings. Antimicrob Agents Chemother. 2014;58(8):4814-25.

101. Health Protection Agency. Weekly report. Potentially transferable linezolid resistance in Enterococcus faecium in Scotland. Eurosurveillance. 2012:46(33):276-83.

102. Ho CC, Yuen KY, Lau SKP, Woo PCY. Rapid identification and validation of specific molecular targets for detection of Escherichia coli O104:H4 outbreak strain by use of high-throughput sequencing data from nine genomes. J Clin Microbiol. 2011;49(10):3714-6.

103. Holden MT, Hsu LY, Kurt K, Weinert LA, Mather AE, Harris SR, et al. A genomic portrait of the emergence, evolution, and global spread of a methicillin-resistant Staphylococcus aureus pandemic. Genome Res. 2013;23:653-64.

104. Hung GC, Nagamine K, Li B, Lo SC. Identification of DNA signatures suitable for use in development of real-time PCR assays by whole-genome sequence approaches: use of Streptococcus pyogenes in a pilot study. J Clin Microbiol. 2012;50(8):2770-3.

105. Huo L, Rachid S, Stadler M, Wenzel SC, Müller R. Synthetic biotechnology to study and engineer ribosomal bottromycin biosynthesis. Chem Biol. 2012;19(10):1278-87.

106. Ibrahim EH, Sherman G, Ward S, Fraser VJ, Kollef MH. The influence of inadequate antimicrobial treatment of bloodstream infections on patient outcomes in the ICU setting. Chest. 2000;118(1):146-55. 
107. loerger TR, O'Malley T, Liao R, Guinn KM, Hickey MJ, Mohaideen N, et al. Identification of new drug targets and resistance mechanisms in Mycobacterium tuberculosis. PLoS One. 2013. doi:10.1371/journal.pone.0075245.

108. Ishii $Y$, Eto M, Mano $Y$, Tateda $K$, Yamaguchi $K$. In vitro potentiation of carbapenems with ME1071, a novel metallo- $\beta$-lactamase inhibitor, against metallo- $\beta$-lactamase-producing Pseudomonas aeruginosa clinical isolates. Antimicrob Agents Chemother. 2010;54:3625-9.

109. Izumiya H, Sekizuka T, Nakaya H, Taguchi M, Oguchi A, Ichikawa N, et al. Whole-genome analysis of Salmonella enterica serovar Typhimurium T000240 reveals the acquisition of a genomic island involved in multidrug resistance via IS1 derivatives on the chromosome. Antimicrob Agents Chemother. 2011;55(2):623-30.

110. Jacoby GA. AmpC beta-lactamases. Clin Microbiol Rev. 2009;22:161-82.

111. Jain A, Awasthi A, Kumar M. Etiological and antimicrobial susceptibility profile of nosocomial blood stream infections in neonatal intensive care unit. Indian J Med Microbiol. 2007;25(3):299-300.

112. Janda JM, Abbott SL. 16 S rRNA gene sequencing for bacterial identification in the diagnostic laboratory: pluses, perils, and pitfalls. J Clin Microbiol. 2007:45(9):2761-4.

113. Jeukens J, Boyle B, Kukavica-Ibrulj I, Ouellet MM, Aaron SD, Charette SJ, et al. Comparative genomics of isolates of a Pseudomonas aeruginosa epidemic strain associated with chronic lung infections of cystic fibrosis patients. PLoS One. 2014. doi:10.1371/journal.pone.0087611.

114. Joensen KG, Scheutz F, Lund O, Hasman H, Kaas RS, Nielsen EM, et al. Real-time whole-genome sequencing for routine typing, surveillance, and outbreak detection of verotoxigenic Escherichia coli. J Clin Microbiol. 2014;52(5):1501-10.

115. Jolley KA, Hill DM, Bratcher HB, Harrison OB, Feavers IM, Parkhill J, et al. Resolution of a meningococcal disease outbreak from whole-genome sequence data with rapid web-based analysis methods. J Clin Microbiol. 2012;50(9):3046-53.

116. Jolley KA, Maiden MC. BIGSdb: scalable analysis of bacterial genome variation at the population level. BMC Bioinformatics. 2010;11:595.

117. Jones K, Patel NG, Levy MA, Storeygard A, Balk D, Gittleman JL, et al. Global trends in emerging infectious diseases. Nature. 2008;451:990-3.

118. Jorgensen $\mathrm{JH}$, Ferraro MJ. Antimicrobial susceptibility testing: a review of general principles and contemporary practices. Clin Infect Dis. 2009;49(11):1749-55.

119. Kallifidas D, Kang HS, Brady SF. Tetarimycin A, an MRSA-active antibiotic identified through induced expression of environmental DNA gene clusters. J Am Chem Soc. 2012;134(48):19552-5.

120. Karch H, Tarr PI, Bielaszewska M. Enterohaemorrhagic Escherichia coli in human medicine. Int J Med Microbiol. 2005:295:405-18.

121. Kato-Maeda M, Ho C, Passarelli B, Banaei N, Grinsdale J, Flores L, et al. Use of whole genome sequencing to determine the microevolution of Mycobacterium tuberculosis during an outbreak. PLoS One. 2013. doi:10.1371/journal.pone.0058235.

122. Kodali S, Galgoci A, Young K, Painter R, Silver LL, Herath KB, et al. Determination of selectivity and efficacy of fatty acid synthesis inhibitors. J Biol Chem. 2005;280:1669-77

123. Kollef MH, Sherman G, Ward S, Fraser VJ. Inadequate antimicrobial treatment of infections: a risk factor for hospital mortality among critically III patients. Chest. 1999;115(2):462-74.

124. Kos VN, Déraspe M, McLaughlin RE, Whiteaker JD, Roy PH, Alm RA, et al. The resistome of Pseudomonas aeruginosa in relationship to phenotypic susceptibility. Antimicrob Agents Chemother. 2015;59(1):427-36.

125. Köser CU, Bryant JM, Comas I, Feuerriegel S, Niemann S, Gagneux S, et al. Comment on: characterization of the embB gene in Mycobacterium tuberculosis isolates from Barcelona and rapid detection of main mutations related to ethambutol resistance using a low-density DNA array. J Antimicrob Chemother. 2014;69(8):2298-9.

126. Köser CU, Ellington MJ, Cartwright EJ, Gillespie SH, Brown NM, Farrington M, et al. Routine use of microbial whole genome sequencing in diagnostic and public health microbiology. PLoS Pathog. 2012. doi:10.1371/journal.ppat.1002824.

127. Köser CU, Ellington MJ, Peacock SJ. Whole-genome sequencing to control antimicrobial resistance. Trends Genet. 2014;30(9):401-7.

128. Köser CU, Feuerriegel S, Summers DK, Archer JA, Niemann S. Importance of the genetic diversity within the Mycobacterium tuberculosis complex for the development of novel antibiotics and diagnostic tests of drug resistance. Antimicrob Agents Chemother. 2012;56(12):6080-7.

129. Köser CU, Fraser LJ, loannou A, Becq J, Ellington MJ, Holden MT, et al. Rapid single-colony whole-genome sequencing of bacterial pathogens. J Antimicrob Chemother. 2014;69(5):1275-81.
130. Köser CU, Holden MTG, Ellington MJ, Cartwright EJP, Brown NM, Ogilvy-Stuart $\mathrm{AL}$, et al. Rapid whole-genome sequencing for investigation of a neonatal MRSA outbreak. N Engl J Med. 2012;366:2267-75.

131. Kumar S, Rizvi M, Vidhani S, Sharma VK. Changing face of septicaemia and increasing drug resistance in blood isolates. Indian J Pathol Microbiol. 2004;47(3):441-6.

132. Kumar $V$, Sun $P$, Vamathevan J, Li Y, Ingraham K, Palmer L, et al. Comparative genomics of Klebsiella pneumoniae strains with different antibiotic resistance profiles. Antimicrob Agents Chemother. 2011;55(9):4267-76.

133. Kyrpides NC. Fifteen years of microbial genomics: meeting the challenges and fulfilling the dream. Nature Biotech. 2009;27:627-32.

134. Kyrpides NC, Hugenholtz P, Eisen JA, Woyke T, Goker M, Parker CT, et al. Genomic encyclopedia of bacteria and Archaea: sequencing a myriad of type strains. PLoS Biol. 2014. doi:10.1371/journal.pbio.1001920.

135. Larsen MV. Internet-based solutions for analysis of next-generation sequence data. J Clin Microbiol. 2013:51(9):3162.

136. Larsen MV, Cosentino S, Rasmussen S, Friis C, Hasman H, Marvig RL, et al. Multilocus sequence typing of total-genome-sequenced bacteria. J Clin Microbiol. 2012;50:1355-61

137. Larsen MH, Vilcheze C, Kremer L, Besra GS, Parsons L, Salfinger M, et al. Overexpression of inhA, but not kasA, confers resistance to isoniazid and ethionamide in Mycobacterium smegmatis, M. bovis BCG and M. tuberculosis. Mol Microbiol. 2002;46:453-66.

138. Le VT, Diep BA. Selected insights from application of whole-genome sequencing for outbreak investigations. Curr Opin Crit Care. 2013;19:432-9.

139. Lee JY, Ko KS. Mutations and expression of PmrAB and PhoPQ related with colistin resistance in Pseudomonas aeruginosa clinical isolates. Diagn Microbiol Infect Dis. 2014;78(3):271-6.

140. Leekitcharoenphon P, Kaas RS, Thomsen MCF, Friis C, Rasmussen S, Aarestrup FM. SnpTree-a web-server to identify and construct SNP trees from whole genome sequence data. BMC Genomics. 2012; Suppl 7. doi:10.1186/1471-2164-13-S7-S6

141. Leekitcharoenphon P, Nielsen EM, Kaas RS, Lund O, Aarestrup FM. Evaluation of whole genome sequencing for outbreak detection of Salmonella enterica. PLoS One. 2014. doi:10.1371/journal.pone.0087991.

142. Lewis T, Loman NJ, Bingle L, Jumaa P, Weinstock GM, Mortiboy D, et al. High-throughput whole-genome sequencing to dissect the epidemiology of Acinetobacter baumannii isolates from a hospital outbreak. J Hosp Infect. 2010;75(1):37-41.

143. Li M, Du X, Villaruz AE, Diep BA, Wang D, Song Y, et al. MRSA epidemic linked to a quickly spreading colonization and virulence determinant. Nat Med. 2012;18:816-9.

144. Lipkin WI, Firth C. Viral surveillance and discovery. Curr Opin Virol. 2013;3:199-204.

145. Liu P, Li P, Jiang X, Bi D, Xie Y, Tai C, et al. Complete genome sequence of Klebsiella pneumoniae subsp. pneumoniae HS11286, a multidrug-resistant strain isolated from human sputum. J Bacteriol. 2012;194(7):1841-2.

146. Liu B, Pop M. ARDB-antibiotic resistance genes database. Nucleic Acids Res. 2009. doi:10.1093/nar/gkn656.

147. Liu A, Tran L, Becket E, Lee K, Chinn L, Park E, et al. Antibiotic sensitivity profiles determined with an Escherichia coli gene knockout collection: generating an antibiotic bar code. Antimicrob Agents Chemother. 2010;54:1393-403.

148. Livermore DM. Discovery research: the scientific challenge of finding new antibiotics. J Antimicrob Chemother. 2011;66(9):1941-4.

149. Loman NJ, Constantinidou C, Chan JZ, Halachev M, Sergeant M, Penn CW, et al. High-throughput bacterial genome sequencing: an embarrassment of choice, a world of opportunity. Nat Rev Microbiol. 2012;10:599-606.

150. Loman NJ, Constantinidou C, Christner M, Rohde H, Chan JZ, Quick J, et al. A culture-independent sequence-based metagenomics approach to the investigation of an outbreak of Shiga-toxigenic Escherichia coli 0104:H4. JAMA. 2013;309:1502-10.

151. López-Camacho E, Gómez-Gil R, Tobes R, Manrique M, Lorenzo M, Galván B, et al. Genomic analysis of the emergence and evolution of multidrug resistance during a Klebsiella pneumonia outbreak including carbapenem and colistin resistance. J Antimicrob Chemother. 2014;69(3):632-6.

152. Luckey TD. Introduction to intestinal microecology. Am J Clin Nutr. 1972;25:1292-4.

153. Lupien A, Gingras H, Bergeron MG, Leprohon P, Ouellette M. Multiple mutations and increased RNA expression in tetracycline-resistant Streptococcus pneumonia as determined by genome-wide DNA and mRNA sequencing. J Antimicrob Chemother. 2015. doi:10.1093/jac/dkv060. 
154. Malpartida F, Hopwood DA. Physical and genetic characterisation of the gene cluster for the antibiotic actinorhodin in Streptomyces coelicolor A3(2). Mol Gen Genet. 1986;205(1):66-73.

155. Mardanov MM, Babykin AV, Beletsky AV, Grigoriev Al, Zinchenko W, Kadnikov $W$, et al. Metagenomic analysis of the dynamic changes in the gut microbiome of the participants of the MARS-500 experiment, simulating long term space flight. Acta Nat. 2013;5(3):116-25.

156. McAdam PR, Templeton KE, Edwards GF, Holden MT, Feil EJ, Aanensen DM, et al. Molecular tracing of the emergence, adaptation, and transmission of hospital-associated methicillin-resistant Staphylococcus aureus. Proc Natl Acad Sci U S A. 2012;109(23):9107-12.

157. McCarthy AJ, van Wamel W, Vandendriessche S, Larsen J, Denis O, Garcia-Graells C, et al. Staphylococcus aureus CC398 clade associated with human-to-human transmission. Appl Environ Microbiol. 2012;78(24):8845-8.

158. McGann P, Hang J, Clifford RJ, Yang Y, Kwak YI, Kuschner RA, et al. Complete sequence of a novel 178-kilobase plasmid carrying bla $a_{(\mathrm{NDM}-1)}$ in a Providencia stuartii strain isolated in Afghanistan. Antimicrob Agents Chemother. 2012;56:1673-9.

159. Mellmann A, Harmsen D, Cummings CA, Zentz EB, Leopold SR, Rico A, et al. Prospective genomic characterization of the German enterohemorrhagic Escherichia coli O104:H4 outbreak by rapid next-generation sequencing technology. PLoS One. 2011. doi:10.1371/journal.pone.0022751.

160. Milillo M, Kwak YI, Snesrud E, Waterman PE, Lesho E, McGann P. Rapid and simultaneous detection of blaKPC and blaNDM by use of multiplex real-time PCR. J Clin Microbiol. 2013;51(4):1247-9.

161. Minnesota Department of Health. Antimicrobial susceptibilities of selected pathogens (MDH antibiogram). 2013. Accessed 4 December 2014.

162. Miró E, Segura C, Navarro F, Sorlí L, Coll P, Horcajada JP, et al. Spread of plasmids containing the bla $a_{(\mathrm{VIM}-1)}$ and $b a_{(\mathrm{CTX}-\mathrm{M})}$ genes and the qnr determinant in Enterobacter cloacae, Klebsiella pneumoniae and Klebsiella oxytoca isolates. J Antimicrob Chemother. 2010;65(4):661-5.

163. Miyoshi-Akiyama T, Kuwahara T, Tada T, Kitao T, Kirikae T. Complete genome sequence of highly multidrug-resistant Pseudomonas aeruginosa NCGM2.S1, a representative strain of a cluster endemic to Japan. J Bacteriol. 2011;193(24):7010.

164. Mobegi FM, van Hijum SA, Burghout $P$, Bootsma HJ, de Vries SP, van der Gaast-de Jongh CE, et al. From microbial gene essentiality to novel antimicrobial drug targets. BMC Genomics. 2014;15(1):958.

165. Mowat E, Paterson S, Fothergill JL, Wright EA, Ledson MJ, Walshaw MJ, et al. Pseudomonas aeruginosa population diversity and turnover in cystic fibrosis chronic infections. Am J Res Crit Care Med. 2011;183:1674-9.

166. Mugnier PD, Poirel L, Nordmann P. Functional analysis of insertion sequence ISAba1, responsible for genomic plasticity of Acinetobacter baumannii. J Bacteriol. 2009;191:2414-8.

167. Muller B, Borrell S, Rose G, Gagneux S. The heterogeneous evolution of multidrug resistant Mycobacterium tuberculosis. Trends Genet. 2013;29:160-9.

168. Mutreja A, Kim DW, Thomson NR, Connor TR, Lee JH, Kariuki S, et al. Evidence for several waves of global transmission in the seventh cholera pandemic. Nature. 2011;477(7365):462-5.

169. Nair D. Whole-genome sequencing and infectious disease: a novel application of sequencing technology. Genetic testing and molecular biomarkers. 2013;17(10):719-20.

170. Custodio HT. Hospital Acquired Infections. 2014. http://emedicine.medscape. com/article/967022-overview. Accessed 14 July 2015

171. Nickerson EK, Hongsuwan M, Limmathurotsakul D, Wuthiekanun V, Shah KR, Srisomang $P$, et al. Staphylococcus aureus bacteraemia in a tropical setting: patient outcome and impact of antibiotic resistance. PLoS One. 2009. doi:10.1371/journal.pone.0004308.

172. Nickerson EK, West TE, Day NP, Peacock SJ. Staphylococcus aureus disease and drug resistance in resource-limited countries in South and East Asia. Lancet Infect Dis. 2009;9:130-5.

173. Nigro SJ, Farrugia DN, Paulsen IT, Hall RM. A novel family of genomic resistance islands, AbGRI2, contributing to aminoglycoside resistance in Acinetobacter baumannii isolates belonging to global clone 2. J Antimicrob Chemother. 2013;68(3):554-7.

174. Octavia S, Wang Q, Tanaka MM, Kaur S, Sintchenko V, Lan R. Delineating community outbreaks of Salmonella enterica serovar Typhimurium using whole genome sequencing: insights into genomic variability within an outbreak. J Clin Microbiol. 2015;53(4):1063-71.

175. Ogunremi D, Devenish J, Amoako K, Kelly H, Dupras AA, Belanger S, et al. High resolution assembly and characterization of genomes of Canadian isolates of Salmonella Enteritidis. BMC Genomics. 2014;15(1):713.
176. Ogunremi D, Kelly H, Dupras AA, Belanger S, Devenish J. Development of a new molecular subtyping tool for Salmonella enterica serovar Enteritidis based on single nucleotide polymorphism genotyping using PCR. J Clin Microbiol. 2014;52(12):4275-85.

177. Okoro CK, Kingsley RA, Connor TR, Harris SR, Parry CM, Al-Mashhadani MN, et al. Intracontinental spread of human invasive Salmonella Typhimurium pathovariants in sub-Saharan Africa. Nat Genet. 2012;44:1215-21.

178. Okoro CK, Kingsley RA, Quail MA, Kankwatira AM, Feasey NA, Belanger $S$, et al. High-resolution single nucleotide polymorphism analysis distinguishes recrudescence and reinfection in recurrent invasive nontyphoidal Salmonella Typhimurium disease. Clin Infect Dis. 2012:54:955-63.

179. Otter JA, Patel A, Cliff PR, Halligan EP, Tosas O, Edgeworth JD. Selection for qaCA carriage in CC22, but not CC30, methicillin-resistant Staphylococcus aureus bloodstream infection isolates during a successful institutional infection control programme. J Antimicrob Chemother. 2013;68:992-9.

180. Pace NR. Mapping the tree of life: progress and prospects. Microbiol Mol Biol Rev. 2009;73:565-76.

181. Pagani I, Liolios K, Jansson J, Chen IM, Smirnova T, Nosrat B, et al. The Genomes OnLine Database (GOLD) v.4: status of genomic and metagenomic projects and their associated meta-data. Nucleic Acids Res. 2012. doi:10.1093/nar/gkr1100.

182. Palmer AC, Kishony R. Understanding, predicting and manipulating the genotypic evolution of antibiotic resistance. Nat Rev Genetics. 2013;14:243-8.

183. Palomino JC, Martin A. TMC207 becomes bedaquiline, a new anti-TB drug. Future Microbiol. 2013;8(9):1071-80.

184. Paterson GK, Harrison EM, Holmes MA. The emergence of mecC methicillin-resistant Staphylococcus aureus. Trends Microbiol. 2014;22(1):42-7

185. Payne DJ, Gwynn MN, Holmes DJ, Pompliano DL. Drugs for bad bugs: confronting the challenges of antibacterial discovery. Nat Rev Drug Discov. 2007;6:29-40.

186. Perez-Lago L, Comas I, Navarro Y, González-Candelas F, Herranz M, Bouza $E$, et al. Whole genome sequencing analysis of intrapatient microevolution in Mycobacterium tuberculosis: potential impact on the inference of tuberculosis transmission. J Infect Dis. 2014;209:98-108.

187. Pethe K, Bifani P, Jang J, Kang S, Park S, Ahn S, et al. Discovery of Q203, a potent clinical candidate for the treatment of tuberculosis. Nat Med. 2013;19:1157-60

188. Petty NK, Ben Zakour NL, Stanton-Cook M, Skippington E, Totsika M, Forde $\mathrm{BM}$, et al. Global dissemination of a multidrug resistant Escherichia coli clone Proc Natl Acad Sci U S A. 2014;111(15):5694-9.

189. Podschun R, Ullmann U. Klebsiella spp. as nosocomial pathogens: epidemiology, taxonomy, typing methods, and pathogenicity factors. Clin Microbiol Rev. 1998;11:589-603.

190. Poirel L, Jayol A, Bontron S, Villegas MV, Ozdamar M, Türkoglu S, et al. The mgrB gene as a key target for acquired resistance to colistin in Klebsiella pneumoniae. J Antimicrob Chemother. 2015;70(1):75-80.

191. Pontali E, Matteelli A, Migliori GB. Drug-resistant tuberculosis. Curr Opin Pulm Med. 2013;19(3):266-72

192. Price LB, Stegger M, Hasman H, Aziz M, Larsen J, Andersen PS, et al. Staphylococcus aureus CC398: host adaptation and emergence of methicillin resistance in livestock. MBio. 2012. doi:10.1128/mBio.00305-11.

193. Pritchard L, Holden NJ, Bielaszewska M, Karch H, Toth IK. Alignment-free design of highly discriminatory diagnostic primer sets for Escherichia coli 0104:H4 outbreak strains. PLoS One. 2012. doi:10.1371/journal.pone.0034498.

194. Public Health England. Carbapenemase-producing Enterobacteriaceae: early detection, management and control toolkit for acute trusts. 2014 https://www.gov.uk/government/publications/carbapenemase-producing-enterobacteriaceae-early-detection-management-and-control-toolkit-for-acute-trusts. Accessed 15 December 2014.

195. Rasko DA, Webster DR, Sahl JW, Bashir A, Boisen N, Scheutz F, et al. Origins of the E. coli strain causing an outbreak of hemolytic-uremic syndrome in Germany. N Engl J Med. 2011;365(8):709-17.

196. Read TD, Massey RC. Characterizing the genetic basis of bacterial phenotypes using genome-wide association studies: a new direction for bacteriology. Genome Med. 2014;6(11):109.

197. Remuinan MJ, Perez-Herran E, Rullas J, Alemparte C, Martinez-Hoyos M, Dow DJ, et al. Tetrahydropyrazolo[1,5-a]pyrimidine-3-carboxamide and N-benzyl-60,70-dihydrospiro[piperidine-4,4'-thieno[3,2-c]pyran] analogues 
with bactericidal efficacy against Mycobacterium tuberculosis targeting MmpL3. PLoS One. 2013. doi:10.1371/journal.pone.0060933.

198. Reuter S, Harrison TG, Köser CU, Ellington MJ, Smith GP, Parkhill J, et al. A pilot study of rapid whole-genome sequencing for the investigation of a Legionella outbreak. BMJ Open. 2013;3:1-6.

199. Rieber N, Zapatka M, Lasitschka B, Jones D, Northcott P, Hutter B, et al. Coverage bias and sensitivity of variant calling for four whole-genome sequencing technologies. PLoS One. 2013. doi:10.1371/journal.pone.0066621.

200. Riley DR, Sieber KB, Robinson KM, White JR, Ganesan A, Nourbakhsh S, et al. Bacteria-human somatic cell lateral gene transfer is enriched in cancer samples. PLoS Comput Biol. 2013. doi:10.1371/journal.pcbi.1003107.

201. Robinson ER, Walker TM, Pallen MJ. Genomics and outbreak investigation: from sequence to consequence. Genome Medicine. 2013;5(4):36.

202. Roetzer A, Diel R, Kohl TA, Rückert C, Nübel U, Blom J, et al. Whole genome sequencing versus traditional genotyping for investigation of a Mycobacterium tuberculosis outbreak: a longitudinal molecular epidemiological study. PLoS Med. 2013. doi:10.1371/journal.pmed.1001387.

203. Rohde H, Qin J, Cui Y, Li D, Loman NJ, Hentschke M, et al. Open-source genomic analysis of Shiga-toxin-producing E. coli O104:H4. N Engl J Med. 2011;365(8):718-24.

204. Rolain JM, Diene SM, Kempf M, Gimenez G, Robert C, Raoult D. Real-time sequencing to decipher the molecular mechanism of resistance of a clinical pan-drug-resistant Acinetobacter baumannii isolate from Marseille, France. Antimicrob Agents Chemother. 2013;57(1):592-6.

205. Sabat AJ. Detection of new methicillin-resistant Staphylococcus aureus strains that carry a novel genetic homologue and important virulence determinants. J Clin Microbiol. 2012;50:3374-7.

206. Sabat AJ, Budimir A, Nashev D, Sá-Leão R, van Dijl JM, Laurent F, et al. On behalf of the ESCMID Study Group of Epidemiological Markers (ESGEM). Overview of molecular typing methods for outbreak detection and epidemiological surveillance. Euro Surveill. 2013;18(4):20380.

207. Satoshi O, Yoko T, Yong-Pil K, Hideaki H, Hiroshi K, Makoto S, et al. New KB-3346-5 substance and method for producing the same. Japanese patent JP2009046404. 2009.

208. Scazzocchio C. Fungal biology in the post-genomic era. Fungal Biology and Biotechnology. 2014;1(1):7.

209. Schürch AC, Kremer K, Daviena O, Kiers A, Boeree MJ, Siezen RJ, et al, High-resolution typing by integration of genome sequencing data in a large tuberculosis cluster. J Clin Microbiol. 2010:48(9):3403-6.

210. Sekizuka T, Matsui M, Yamane K, Takeuchi F, Ohnishi M, Hishinuma $A$, et al. Complete sequencing of the bla $a_{(\mathrm{NDM}-1)}$-positive IncA/C plasmid from Escherichia coli ST38 isolate suggests a possible origin from plant pathogens. PLoS One. 2011. doi:10.1371/journal.pone.0025334.

211. Seth-Smith HM, Harris SR, Skilton RJ, Radebe FM, Golparian D, Shipitsyna $E$, et al. Whole-genome sequences of Chlamydia trachomatis directly from clinical samples without culture. Genome Res. 2013;23(5):855-66.

212. Shahada F, Sekizuka T, Kuroda M, Kusumoto M, Ohishi D, Matsumoto A et al. Characterization of Salmonella enterica serovar typhimurium isolates harboring a chromosomally encoded CMY-2 $\beta$-lactamase gene located on a multidrug resistance genomic island. Antimicrob Agents Chemother. 2011;55(9):4114-21.

213. Shepheard MA, Fleming VM, Connor TR, Corander J, Feil EJ, Fraser C, et al. Historical zoonoses and other changes in host tropism of Staphylococcus aureus, identified by phylogenetic analysis of a population dataset. PLOS One. 2013. doi:10.1371/journal.pone.0062369.

214. Silver LL. Challenges of antibacterial discovery. Clin Microbiol Rev. 2011;24(1):71-109.

215. Snitkin ES, Zelazny AM, Montero Cl, Stock F, Mijares L. Genome-wide recombination drives diversification of epidemic strains of Acinetobacter baumannii. Proc Natl Acad Sci U S A. 2011;108(33):13758-63.

216. Snitkin ES, Zelazny AM, Thomas PJ, Stock F. Tracking a hospital outbreak of carbapenem-resistant Klebsiella pneumoniae with whole-genome sequencing. Sci Transl Med. 2012. doi:10.1126/scitransImed.3004129.

217. Solomon SL, Oliver KB. Antibiotic resistance threats in the United States: stepping back from the brink. Am Fam Physician. 2014;89(12):938-41.

218. Stoesser N, Batty EM, Eyre DW, Morgan M, Wyllie DH, Del Ojo EC, et al. Predicting antimicrobial susceptibilities for Escherichia coli and Klebsiella pneumoniae isolates using whole genomic sequence data. J Antimicrob Chemother. 2013;68(10):2234-44.
219. Sundsfjord A, Simonsen GS, Haldorsen BC, Haaheim H, Hjelmevoll SO, Littauer $\mathrm{P}$, et al. Genetic methods for detection of antimicrobial resistance. APMIS. 2004;112:815-37.

220. Swinney DC, Anthony J. How were new medicines discovered? Nat Rev Drug Discov. 2011;10:507-19.

221. Sydnor ERM, Perl TM. Hospital epidemiology and infection control in acute-care settings. Clin Microbiol Rev. 2011;24(1):141-73.

222. Tang YW, Procop GW, Persing DH. Molecular diagnostics of infectious diseases. Clin Chem. 1997;43(11):2021-38.

223. Tenover FC, Canton R, Kop J, Chan R, Ryan J, Weir F, et al. Detection of colonization by carbapenemase-producing Gram-negative Bacilli in patients by use of the Xpert MDRO assay. J Clin Microbiol. 2013;51(11):3780-7.

224. The Regional Committee for the Eastern Mediterranean Region. Annual report of the Regional Director for 2012 and progress reports. Resolution EM/RC60/R.1. 2013. http://www.emro.who.int/about-who/rc60/index.html. Accessed 20 December 2014.

225. Thomas CM, Nielsen KM. Mechanisms of, and barriers to, horizontal gene transfer between bacteria. Nat Rev Microbiol. 2005;3(9):711-21.

226. Thye T, Vannberg FO, Wong SH, Owusu-Dabo E, Osei I, Gyapong J, et al. Genome-wide association analyses identifies a susceptibility locus for tuberculosis on chromosome 18q11.2. Nature Genet. 2010;42:739-41.

227. Tong SY, Holden MT, Nickerson EK, Cooper BS, Köser CU, Cori A, et al. Genome sequencing defines phylogeny and spread of methicillin-resistant Staphylococcus aureus in a high transmission setting. Genome Res. 2015;25(1):111-8.

228. Török ME, Harris SR, Cartwright EJ, Raven KE, Brown NM, Allison ME, et al, Zero tolerance for healthcare-associated MRSA bacteraemia: is it realistic? J Antimicrob Chemother. 2014;69:2238-45.

229. Uchiyama I, Mihara M, Nishide H, Chiba H. MBGD update 2015: microbial genome database for flexible ortholog analysis utilizing a diverse set of genomic data. Nucl Acids Res. 2014. doi:10.1093/nar/gku1152.

230. Uhlemann AC, Dumortier C, Hafer C, Taylor BS, Sánchez J, Rodriguez-Taveras C, et al. Molecular characterization of Staphylococcus aureus from outpatients in the Caribbean reveals the presence of pandemic clones. Eur J Clin Microbiol Infect Dis. 2011;31:505-11.

231. Uhlemann AC, Porcella SF, Trivedi S, Sullivan SB, Hafer C, Kennedy AD, et al. Identification of a highly transmissible animal-independent Staphylococcus aureus ST398 clone with distinct genomic and cell adhesion properties. MBio. 2012. doi:10.1128/mBio.00027-12.

232. UK Department of Health. UK five year antimicrobial resistance strategy 2013 to 2018. 2013. https://www.gov.uk/government/publications/ uk-5-year-antimicrobial-resistance-strategy-2013-to-2018. Accessed 15 December 2014.

233. Underwood AP, Dallman T, Thomson NR, Williams M, Harker K, Perry N, et al. Public health value of next-generation DNA sequencing of enterohemorrhagic Escherichia coli isolates from an outbreak. J Clin Microbiol. 2013;51(1):232-7.

234. Usha V, Gurcha SS, Lovering AL, Lloyd AJ, Papaemmanouil A, Reynolds RC, et al. Identification of novel diphenyl urea inhibitors of Mt-GuaB2 active against Mycobacterium tuberculosis. Microbiology. 2011;157:290-9.

235. van Belkum A. Rapid clinical bacteriology and its future impact. Ann Lab Med. 2013;33:14-27.

236. van der Westhuyzen R, Hammons JC, Meier JL, Dahesh S, Moolman WJ, Pelly SC, et al. The antibiotic CJ-15,801 is an antimetabolite that hijacks and then inhibits CoA biosynthesis. Chem Biol. 2012;19(5):559-71.

237. van Nood E, Vrieze A, Nieuwdorp M, Fuentes S, Zoetendal EG, de Vos WM, et al. Duodenal infusion of donor feces for recurrent Clostridium difficile. N Engl J Med. 2013;368:407-15

238. van Opijnen T, Bodi KL, Camilli A. Tn-seq: high-throughput parallel sequencing for fitness and genetic interaction studies in microorganisms. Nat Methods. 2009;6(10):767-72.

239. Vernet G, Saha S, Satzke C, Burgess DH, Alderson M, Maisonneuve JF, et al Laboratory-based diagnosis of pneumococcal pneumonia: state of the art and unmet needs. Clin Microbiol Infect. 2011;17 Suppl 3:1-13.

240. Vidovic S, Caron C, Taheri A, Thakur SD, Read TD, Kusalik A, et al. Using crude whole-genome assemblies of Neisseria gonorrhoeae as a platform for strain analysis: clonal spread of gonorrhea infection in Saskatchewan, Canada. J Clin Microbiol. 2014;52(10):3772-6.

241. Vogel V, Falquet L, Calderon-Copete SP, Basset P, Blanc DS. Short term evolution of a highly transmissible methicillin-resistant Staphylococcus 
aureus clone (ST228) in a tertiary care hospital. PLoS One. 2012. doi:10.1371/journal.pone.0038969.

242. Walker TM, Ip CL, Harrell RH, Evans JT, Kapatai G, Dedicoat MJ, et al. Whole-genome sequencing to delineate Mycobacterium tuberculosis outbreaks: a retrospective observational study. Lancet Infect Dis. 2013;13:137-46.

243. Walsh C. Where will new antibiotics come from? Nat Rev Microbiol. 2003;1 (1):65-70.

244. Wang J, Kodali S, Lee SH, Galgoci A, Painter R, Dorso K, et al. Discovery of platencin, a dual FabF and FabH inhibitor with in vivo antibiotic properties. Proc Natl Acad Sci. 2007;104:7612-6.

245. Ward MJ, Gibbons CL, McAdam PR, van Bunnik BA, Girvan EK, Edwards GF, et al. Time-scaled evolutionary analysis of the transmission and antibiotic resistance dynamics of Staphylococcus aureus CC398. Appl Environ Microbiol. 2014. doi:10.1128/AEM.01777-14.

246. Wilson R, Kumar P, Parashar V, Vilcheze C, Veyron-Churlet R, Freundlich JS, et al. Antituberculosis thiophenes define a requirement for Pks13 in mycolic acid biosynthesis. Nat Chem Biol. 2013;9:499-506.

247. Witney AA, Gould KA, Pope CF, Bolt F, Stoker NG, Cubbon MD, et al. Genome sequencing and characterization of an extensively drug-resistant sequence type 111 serotype 012 hospital outbreak strain of Pseudomonas aeruginosa. Clin Microbiol Infect. 2014;20(10):609-18.

248. Worby CJ, Lipsitch M, Hanage WP. Within-host bacterial diversity hinders accurate reconstruction of transmission networks from genomic distance data. PLoS Comput Biol. 2014. doi:10.1371/journal.pcbi.1003549.

249. World Health Organization (WHO). The evolving threat of antimicrobial resistance: options for action. 2012. http://www.who.int/patientsafety/ implementation/amr/publication/en/. Accessed 1 April 2015.

250. World Health Organization (WHO). The global burden of disease (GBD). 2014. http://www.who.int/healthinfo/global_burden_disease/ GBD_report_2004update_full.pdf Accessed 4 December 2014.

251. World Health Organization (WHO). Antimicrobial resistance: global report on surveillance. 2014. http://www.who.int/drugresistance/ documents/surveillancereport/en/. Accessed 5 December 2014.

252. World Health Organization (WHO). Global Health Observatory (GHO) data. World Health Statistics (full report). 2014. http://www.who.int/gho/ publications/world_health_statistics/2014/en/. Accessed 15 April 2015.

253. Wright GD. The antibiotic resistome: the nexus of chemical and genetic diversity. Nat Rev Microbiol. 2007;5(3):175-86.

254. Wright MS, Haft DH, Harkins DM, Perez F, Hujer KM, Bajaksouzian S, et al. New insights into dissemination and variation of the health care-associated pathogen Acinetobacter baumannii from genomic analysis. MBio. 2014. doi:10.1128/mBio.00963-13.

255. Wylie KM, Weinstock GM, Storch GA. Virome genomics: a tool for defining the human virome. Curr Opin Microbiol. 2013;16:479-84.

256. Wyres KL, Conway TC, Garg S, Queiroz C, Reumann M, Holt K, et al. WGS analysis and interpretation in clinical and public health microbiology laboratories: what are the requirements and how do existing tools compare? Pathogens. 2014;3:437-58.

257. Ye C, Lan R, Xia S, Zhang J, Sun Q, Zhang S, et al. Emergence of a new multidrug-resistant serotype $X$ variant in an epidemic clone of Shigella flexneri. J Clin Microbiol. 2010;48(2):419-26.

258. Young BC, Golubchik T, Batty EM, Fung R, Larner-Svensson $H$, Votintseva AA, et al. Evolutionary dynamics of Staphylococcus aureus during progression from carriage to disease. Proc Natl Acad Sci U S A. 2012;109:4550-5.

259. Young $\mathrm{K}$, Jayasuriya $\mathrm{H}$, Ondeyka JG, Herath $\mathrm{K}$, Zhang $\mathrm{CW}$, Kodali $\mathrm{S}$, et al. Discovery of FabH/FabF inhibitors from natural products. Antimicrob Agents Chemother. 2006;50:519-26.

260. Zankari E, Hasman $H$, Cosentino S, Vestergaard M, Rasmussen S, Lund O, et al. Identification of acquired antimicrobial resistance genes. J Antimicrob Chemother. 2012;67:2640-4.

261. Zankari E, Hasman $H$, Kaas RS, Seyfarth AM, Agersø $Y$, Lund O, et al. Genotyping using whole-genome sequencing is a realistic alternative to surveillance based on phenotypic antimicrobial susceptibility testing J Antimicrob Chemother. 2013;68(4):771-7.

262. Zavascki AP, Carvalhaes CG, Picão RC, Gales AC. Multidrug-resistant Pseudomonas aeruginosa and Acinetobacter baumannii: resistance mechanisms and implications for therapy. Expert Rev Anti Infect Ther. 2010;8(1):71-93.

263. Zhao J, Grant SF. Advances in whole genome sequencing technology. Curr Pharm Biotechnol. 2011;12(2):293-305.
264. Zhao S, Prenger K, Smith L, Messina T, Fan H, Jaeger E, et al. Rainbow: a tool for large-scale whole-genome sequencing data analysis using cloud computing. BMC Genomics. 2013;14:425.

265. Zhou H, Zhang T, Yu D, Pi B, Yang Q, Zhou J, et al. Genomic analysis of the multidrug-resistant Acinetobacter baumannii strain MDR-ZJ06 widely spread in China. Antimicrob Agents Chemother. 2011;55(10):4506-12.

\section{Submit your next manuscript to BioMed Central and take full advantage of:}

- Convenient online submission

- Thorough peer review

- No space constraints or color figure charges

- Immediate publication on acceptance

- Inclusion in PubMed, CAS, Scopus and Google Scholar

- Research which is freely available for redistribution 